\title{
CULTURA DO TRÂNSITO EM PORTO ALEGRE: ETNOGRAFIA DA COMPANHIA CARRIS PORTO-ALEGRENSE NAS NARRATIVAS DE SEUS TRABALHADORES E HABITANTES DA CIDADE
}

\author{
Henrique Palaver Dallago ${ }^{1}$ \\ Cornelia Eckert (orientação) ${ }^{2}$
}

\section{Introdução}

A Companhia Carris Porto-Alegrense (Carris) faz parte da história da cidade de Porto Alegre. Criada em 1872 não só trouxe a possibilidade de deslocamento e mobilidade urbana aos cidadãos porto-alegrenses como propiciou formas de sociabilidades inéditas na vida do citadino. Romances, flertes, amizades, dramas, diversões, etc. são eventos que povoam a memória dos que se utilizaram desde os primeiros bondes puxados por burros até os modernos ônibus que circulam pela capital gaúcha.

O cenário do início dessa pesquisa em 2006 eram ônibus ditos “comuns”, transitávamos em ônibus de modelos novos pela Carris, seguindo uma rotina de subir ao ônibus, pegar o dinheiro para pagar a passagem ou um "vale” ou, para os estudantes, pegar a carteirinha de estudante e uma “ficha escolar”. Pagávamos ao cobrador e passávamos a roleta. Escolhíamos qualquer lugar no veículo e seguíamos nosso itinerário. Hoje, às portas de 2010, apresenta-se outro cenário. Subimos ao ônibus portando nosso cartão do TRI - Passagem Integrada (sistema de bilhetagem eletrônica) seja de estudante ou de vale-transporte, já não há tantas possibilidades de escolha de assento, visto a ampliação de vagas destinadas aos portadores de necessidades especiais, alguns buscam um lugar propício para assistir as televisões que foram adaptadas as entranhas do veículo e, caso surja a necessidade, podemos ainda usar o "Télo" - serviço que permite ao usuário telefonar de dentro do ônibus.

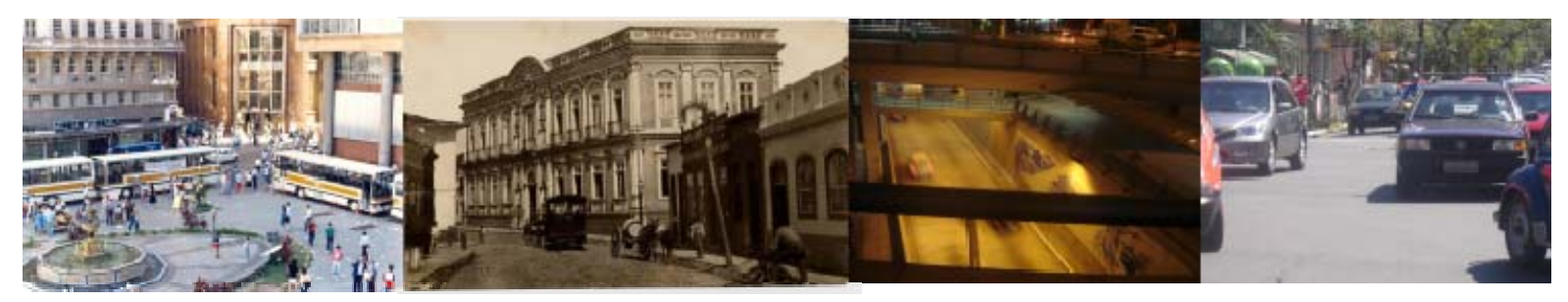

\footnotetext{
${ }^{1}$ Universidade Federal do Rio Grande do Sul, Brasil.

2 Universidade Federal do Rio Grande do Sul, Brasil.
} 
Diante de todo esse cenário de mudanças há um dos principais focos de minha pesquisa: o ônibus-museu Memória Carris. Um ônibus monobloco da década de 1980 que apresenta em seu interior parte da história de Porto Alegre relacionada a evolução dos transportes coletivos na mesma. Eis que se apresentava um paradoxo temporal digno de nota: um ônibus antigo, conduzido por um dos funcionários mais antigos da empresa e que em seu interior abriga desde réplicas de bondes a até mesmo bancos e peças dos veículos que habitavam a paisagem de outra Porto Alegre, hoje viva na memória dos transeuntes e que se faz perdurar na memória coletiva dos porto-alegrense mais jovens através do trabalho realizado pelo museu itinerante Memória Carris.

\section{Apresentando o universo de pesquisa}

Após ter passado por lugares memoráveis da cidade como o antigo Mercado Público e a Avenida João Pessoa esquina com a Sarmento Leite, a atual sede da Companhia Carris Porto-Alegrense situa-se na Rua Albion, 385, Bairro São José. A mais recente sede da Carris, ocupa uma área de $60.000 \mathrm{~m}^{2}$ e é cercada por grandes muros. Muros que são reflexo de um bairro com um alto índice de violência e de assaltos, obrigando a empresa a contar com um forte esquema de segurança para proteger o seu patrimônio.

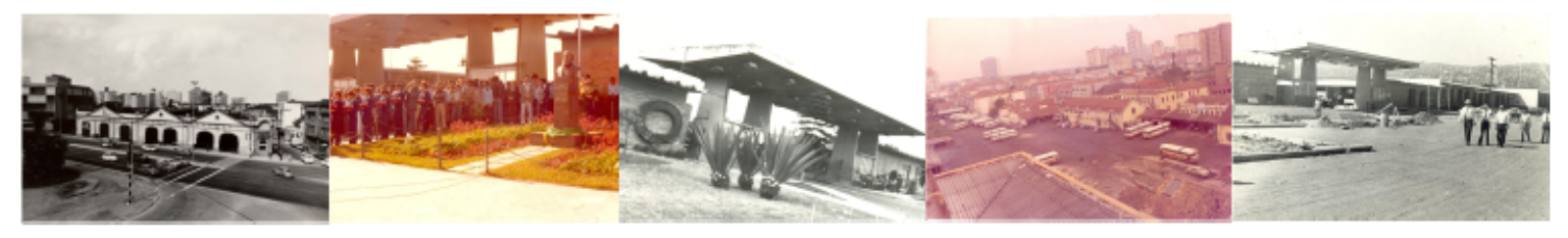

Apesar da aparente hostilidade do lugar, chega-se facilmente na empresa. Conforme vai se chegando, nota-se o grande fluxo de pessoas com uniformes cinzas e simpáticos que caracterizam os funcionários da companhia. Tal símbolo é reflexo da hierarquização que ocorre entre os funcionários: motoristas e cobradores vestem roupas iguais, fiscais são diferentes, o pessoal que trabalha nas funções de manutenção e serviço de limpeza já apresentam outro uniforme (geralmente macacões de cor azul escuro) e os outros funcionários - mais burocráticos do que operativos - vestem-se à “paisana”. É quase como se eles não pertencessem a Carris ou à linha de frente e principal marca da Carris: seus motoristas e cobradores. 
Todos que transitamos pela cidade a bordo de seus veículos de certa forma estamos dentro da Carris, é um amplo universo e cada "carro" ou “caminhão" - como são denominados pelos funcionários - é uma estrela ou planeta desse universo. Mesmo pelo paradoxo que representa o ônibus Memória Itinerante da Carris que, ao mesmo tempo em que leva a memória da empresa em um veículo já fora de linha e transformado em museu, transita pela cidade uma das faces da memória do trânsito e da expansão da urbe. Acabamos por ter a Carris transitando suas próprias memórias em busca de fazer durar sua tradição na cultura do trânsito porto-alegrense, visitando escolas e eventos com finalidades educativas para os quais a Carris é convidada.

Essa extensão da empresa (tanto dos ônibus de linha quanto do Museu Memória ou mesmo dos "fins de linhas") fica evidente no zelo e carinho que os motoristas e cobradores têm pelo seu veículo, mas que às vezes é hábito imposto pelos programas de controle e qualidade que a Carris implementa. Nota-se isso principalmente em época de festa, como as Copas, Natais e outras festividades. Característica que se torna cada vez mais visível e aparente quando estamos dentro de suas dependências “fixas”. Enfim, esse é o amplo universo que trata este artigo: a Carris, suas extensões fixas ou não-fixas. Mas, principalmente, esses sujeitos que, ao narrarem suas peripécias no trânsito porto-alegrense, acabam por fazer durar parte da memória coletiva da cidade de Porto Alegre.

\section{Trajetória de pesquisa}

A pesquisa de iniciação científica no BIEV sobre Cultura do Trânsito foi iniciada em 2007. Fui engajado como "BIC CNPq" no processo de aprendizado da pesquisa sobre memória coletiva em Porto Alegre, tendo por propósito tratar etnograficamente da vida cotidiana tendo por objeto a dinâmica do trânsito, do transporte e dos deslocamentos dos habitantes da cidade a partir de um estudo de caso: os trabalhadores da Companhia Carris Porto-Alegrense (CARRIS), em especial os aposentados.

Para o desenvolvimento do estudo foi necessário, sobretudo tratar teoricamente do fenômeno urbano e da dinâmica da cidade. O principal teórico tratado nesta perspectiva no projeto foi o sociólogo alemão Georg Simmel. Em seu texto As grandes cidades e a vida do espírito de 1903, o autor nos dá preciosas orientações para entendermos não só o comportamento dos indivíduos nas grandes metrópoles como também podemos relacionar tal estado comportamental à cultura do trânsito e a postura que os indivíduos assumem no trânsito. Simmel nos ensina que “o fundamento psicológico sobre o qual se eleva o tipo das 
individualidades da cidade grande é a “intensificação da vida nervosa”, que resulta da mudança rápida e ininterrupta de impressões interiores e exteriores” (Simmel, 1903). É sabido que um dos maiores desafios para o crescimento das cidades é a questão da mobilidade urbana, os deslocamentos rotineiros de milhares de habitantes. Para este processo as administrações municipais, no caso do Brasil, desenvolvem políticas de trânsito e orientações científicas na engenharia do tráfego. Seja em automóveis, motocicletas ou meios de transporte público vemos de forma exacerbada a dita intensificação da vida nervosa.

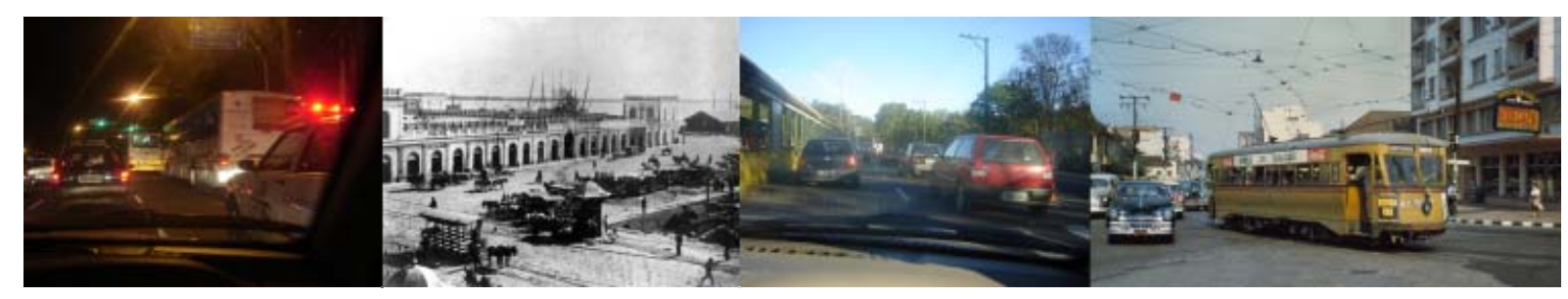

O ritmo de vida das grandes cidades já era muito difícil de ser assimilado quando Simmel escreveu esse texto há 106 anos e hoje, apesar de vermos um cenário mais moderno, suas impressões em relação ao comportamento humano são completamente verificáveis no cotidiano (Simmel, 1903:578). Impressões que ficam não só evidentes como também se intensificam quando vistas de dentro de um automóvel, motocicleta, motocicletas, ônibus, táxis e lotações. Dentro desses “seres” passamos a ter uma outra visão de mundo, tudo fica mais rápido, tudo ganha outro ritmo. Ritmo que às vezes está sob nosso controle parcial como no caso de veículos pessoais ou quando colocamos nosso tempo nas mãos de outra pessoa, como no caso de nos deslocarmos em meios de transporte coletivos. Digo controle parcial, pois quando enfrentamos a situação de engarrafamentos, perdemos tal controle. Verificamos que o nosso tempo extrapola nossa condição de indivíduo e passamos a uma esfera de tempo coletivo.

Simmel ainda nos alerta sobre a importância que esse consenso de tempo comum representa, pois “mediante a acumulação de tantos homens, com interesses tão diferenciados, suas relações e atividades engrenam um organismo tão complexo que, sem a mais exata pontualidade nas promessas e realizações, o todo se esfacelaria em um caos inextricável”, e podemos aplicar isso como típico exemplo para o trânsito.

Assim, vemos a importância que há para a regulação das atividades citadinas a perfeita cadência que deve haver nos horários dos veículos de transporte público. Cadência quebrada 
com grande facilidade se pensarmos que qualquer acidente, engarrafamento ou situação mais inusitada como o atraso de um motorista e/ou cobrador pelos mais variados motivos ocasionam no tempo do indivíduo.

Essa “perda de tempo insuportável” gera uma série de reações que poderiam ser adicionadas a chamada "intensificação da vida de nervosa" tais como o estresse, a ansiedade e até mesmo formas de violência extravasadas através da velocidade e manobras arriscadas, agressões a transeuntes, a motoristas de outros veículos, e mesmo a outros passageiros ou trabalhadores das empresas de transporte coletivo quando é o caso de alguém que se utilize desse serviço.

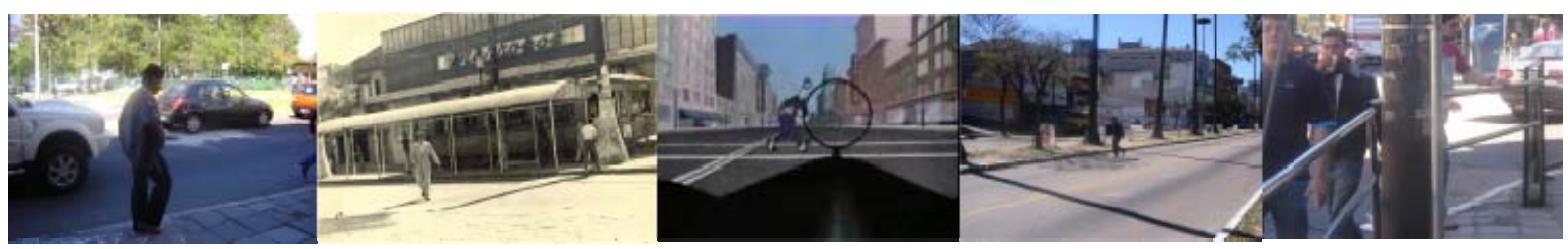

A relação com o risco do trânsito, seja como condutor ou passageiro de veículos, seja como pedestres, revela tensões no contexto cotidiano próprios das formas de viver a cidade. Situação do individualismo moderno que Simmel analisa como formas sociais do viver na cidade, em que predominaria uma atitude blasé em face da necessária acomodação "aos conteúdos e à forma da vida na cidade grande renunciando a reagir a ela - a autoconservação de certas naturezas, sob o preço de desvalorizar todo o mundo objetivo, o que, no final das contas, degrada irremediavelmente a própria personalidade em um sentimento de igual depreciação” (Simmel, 1903:582). Sentimento de depreciação demonstrado e constatado quando vemos condutores e pedestres colocarem a vida em situações de risco como ultrapassar os limites de velocidade, atravessar semáforos fechados, atravessar fora da faixa de segurança, dirigir alcoolizado, etc.

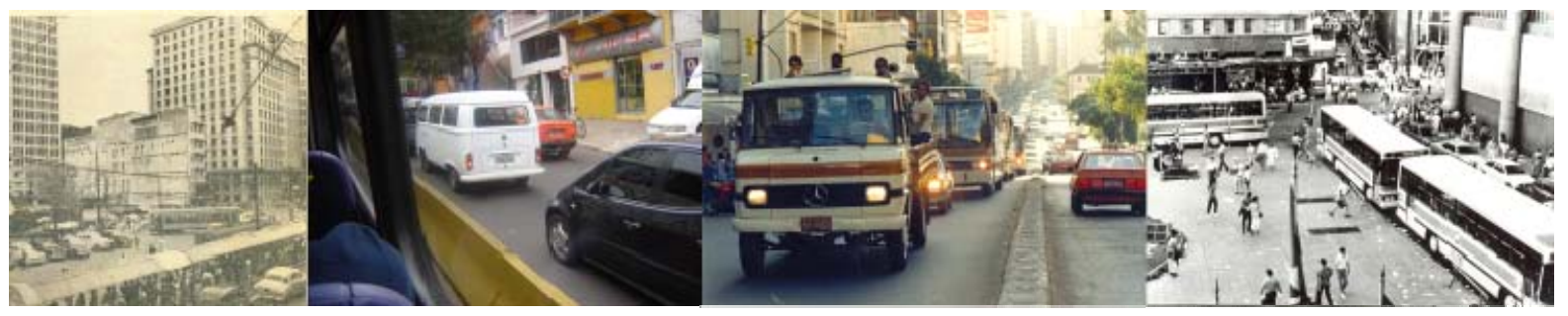


Em Porto Alegre/RS tem se veiculado uma série de campanhas pelos meios de comunicação locais que visam conscientizar os cidadãos sobre questões pertinentes ao trânsito como as campanhas do Grupo RBS “Violência no trânsito: isso tem que ter fim!”, “Correr é o fim!”, “Trânsito no limite” e campanhas e ações sociais promovidas pela Fundação Thiago de Moraes Gonzaga através do Programa VIDA URGENTE. Bem como a recente campanha da Prefeitura Municipal de Porto Alegre intitulada "Respeite o novo sinal de trânsito" (http://www.novosinal.com.br/). As campanhas mencionadas parecem justamente querer agregar elementos modificadores da cultura do trânsito até então vigente.

\title{
Etnografia da Duração
}

O estudo da memória coletiva no BIEV refere-se a uma rítmica de instantes que, na forma descontinua, problematiza o tempo pensado e vivido conforme nos ensina Gaston Bachelard (em A Dialética da Duração, 1994). Para as coordenadoras do Projeto Biev, o estudo da memória coletiva para reconhecer as dinâmicas culturais e simbólicas no contexto urbano, devem ser conquistados por uma etnografia da duração. O conceito de etnografia da duração implica segundo as autoras a pesquisa sobre “a lembrança nos jogos da memória”, onde:

\begin{abstract}
“(...) ao contrário de serem vestígios mnésicos, 'intuição de uma duração’, desprendese do vivido existencial e, no fluxo da imaginação criadora, permite uma "duplicação dos instantes", assegurando-lhe, "nas flutuações do destino, a perenidade de uma substância” (Durand, 1984a, p. 466) ${ }^{3}$. Sob a ótica dos estudos de uma etnografia da duração, a vida urbana é descrita pelos sujeitos-personagens que narram as suas experiências cotidianas nas cidades modernas superpondo os tempos imaginados a partir de um fragmento vivido (Eckert e Rocha, 2009: 46).
\end{abstract}

A pesquisa se dedica a tratar das imagens, das formas, das figurações, dos arranjos da vida humana, enfim que o etnógrafo observa, escuta e analisa (inspiro-me em Cardoso, 2000) o universo simbólico em suas descontinuidades analisados a partir de um microcosmo, o universo de pesquisa em que o pesquisador interage com os pesquisados no processo de campo.

Para construir uma etnografia da duração, é importante reconhecer uma perspectiva arqueológica das tecnologias de deslocamento do ser humano. Para tal, recorre-se a André Leroi-Gourhan na tentativa de juntar os fragmentos que a efemeridade da matéria permitiu ao

\footnotetext{
${ }^{3} \mathrm{O}$ autor baseia-se, assim, no postulado da alternância temporal de que trata Gaston Bachelard em seu tratado sobre a dialética da duração (Bachelard, 1994, p. 31 e 46).
} 
Homem recolher e classificar dos vestígios materiais que sobreviveram à força do tempo e duraram até os nossos dias.

É sabido que uma das práticas mais comuns e necessárias à existência do ser humano é o deslocamento. Prática desenvolvida desde a proto-história e necessária para fins diversos como fugir de alterações climáticas, buscar comida ou vegetação própria para a alimentação de animais já domesticados bem como para se relacionar com tribos vizinhas no intuito de trocas comerciais ou mesmo matrimoniais. Mesmo com o advento da humanidade sedentária, a prática de migração ou os deslocamentos com fins específicos jamais nos deixaram.

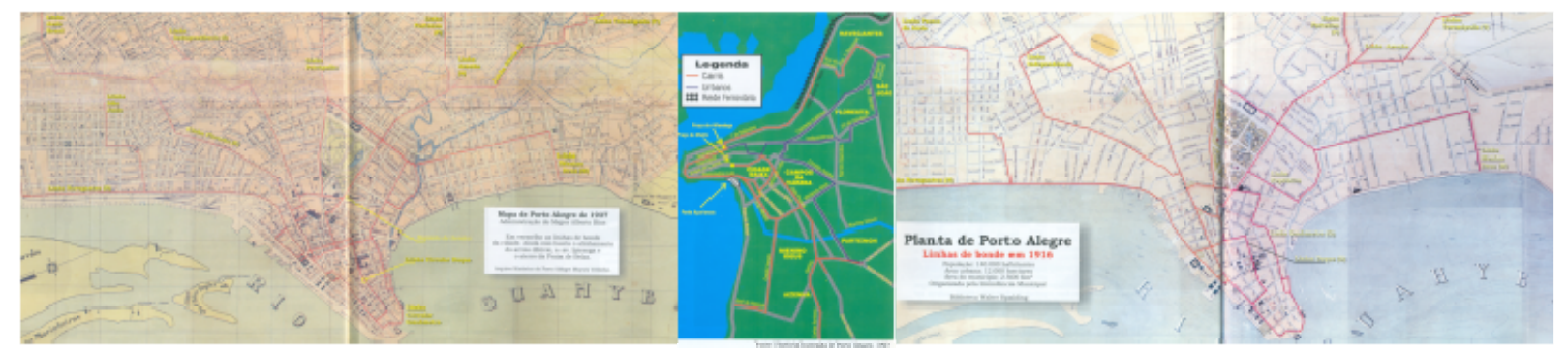

Cada vez que pegamos o carro e "fugimos" do infernal calor de Porto Alegre para alguma praia ou então, tomamos um ônibus em direção às universidades em busca de um saber, aderimos a uma forma da cultura humana. Enfim, as práticas de deslocamento e construção de itinerários podem ser compreendidas nesta configuração de formas. Estes sistemáticos arranjos de formas de viver em vilas, cidades, formas de habitar, de se locomover, falam de um “trajeto antropológico”, termo caro a Gilbert Durand na sua obra As Estruturas Antropológicas do Imaginário (2001), e conceito chave para as antropólogas Ana Luiza Carvalho da Rocha e Cornelia Eckert na pesquisa do BIEV sobre memória coletiva na cidade. Conforme as autoras:

No interior das modernas sociedades complexas a etnografia da duração faz parte da investigação antropológica do dinamismo criador que, no plano do imaginário, reúne o gesto pulsional do sujeito humano e o seu ambiente cósmico e social no interior de uma gênese recíproca. (Eckert e Rocha, 2009: 44).

Também a obra de Michel de Certeau (1994) nos ensina sobre as configurações e formas dos deslocamentos relacionadas às práticas e aos saberes que essas formas engajam. Sendo que "o espaço é um lugar praticado (...) a rua geometricamente definida por um urbanismo é transformada em espaço pelos pedestres” (De Certeau, 1994: 202). Espaço que pode ser estendido aos veículos que transportam os pedestres coletivamente, visto que o 
ônibus passa a ser um espaço de sociabilidade, organizando lugares e fazendo itinerários urbanos. “São percursos de espaço” (De Certeau, 1994: 199).

Podemos sugerir que a humanidade se adapta aos novos arranjos de conglomerar, de trocar, de sociabilidades: vilas, cidades, reciprocidades: uma forma de deslocamento mais moderna que a dos antigos. Hoje, e cada vez mais, será um problema aos urbanistas a expansão das grandes avenidas ou “artérias” (como eram chamadas há não muito tempo atrás) para comportarem o crescimento do número de carros ou de ônibus para suprir a necessidade dos transeuntes, habitantes nas cidades. O deslocamento assim, desponta como um referente central na cultura humana.

Segundo André Leroi-Gourhan "parece perfeitamente demonstrado que o ponto de partida da evolução humana não teve lugar no cérebro mas sim nos pés...” (Leroi-Gourhan, 2002: 24), citação que deixa claro a importância de começarmos a andar de forma ereta, ou seja, alusão ao bipedismo de nossos ancestrais. Ainda em Leroi-Gourhan aprendemos que o deslocar-se de forma ereta, libera nossas mãos para o desenvolvimento de gestos. Gestos que se aprimoram quando a mão é liberada em si da motricidade que, segundo o autor, "é a etapa mais importante, não tanto para o homem como, sobretudo para a sociedade, detentora, coletivamente, dos seus meios de ação” (Leroi-Gourhan, 2002: 44) e, prossegue ensinandonos que o aparecimento da tração animal e de máquinas movidas pela força da água ou mesmo pelo vento "geralmente são concebidos como um fenômeno histórico de significação técnica, como o aparecimento da carroça, da charrua, do moinho, do navio, também devem ser considerados como uma mutação desse organismo externo que, no caso do homem, se substitui ao corpo fisiológico” (Leroi-Gourhan, 2002: 44). É assim que nossa motricidade passa a ser usada não no esforço do movimento em si, mas na orientação ou condução do esforço que ocasionará o movimento.

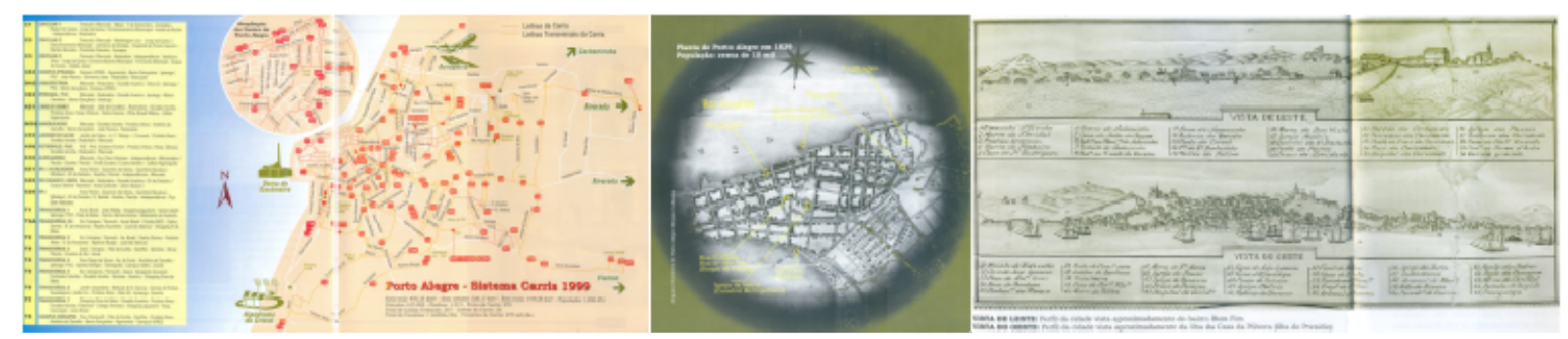


Nas sociedades constatamos duas principais motivações para o deslocamento ou movimentações humanas conforme Leroi-Gourhan em seu primeiro volume de Evolução e Técnicas. A primeira é uma forma pacífica e "que propicia o melhor das aquisições técnicas por ação do comércio” (Leroi-Gourhan, 1984: 89); a segunda ocorre por uma ação guerreira, migratória que leva as sociedades a buscarem estabelecimento em lugares diferentes. Trazendo essas constatações para nossa realidade urbana inferimos que as motivações iniciais para o deslocamento de grupos humanos permanecem as mesmas. É alguma novidade para um típico ser humano tomar um ônibus ou entrar em seu carro e ir para o trabalho? Ou mesmo uma família embarcar em um carro ou avião a fim de gozar de merecidas férias após meses de árduo serviço? Ou mesmo um grupo de adolescentes pegar um ônibus e ir fazer compras e se divertir em algum shopping center? E ainda, o que diríamos do famoso $k_{l}{ }^{4}$ dos trobriandeses que, por tabela, desenvolve uma forma de transporte coletivo entre as Ilhas Trobriand?

A partir desses exemplos fica evidente a cultura do trânsito e a importância da prática dos deslocamentos para o ser humano, como um hábito próprio do ser humano, e novamente evocamos Gilbert Durand (2001) e associar à prática dos deslocamentos à duas de suas dominantes de maneira direta: a dominante postural e a rítmica. Sendo que a dominante digestiva aparece de forma mais sutil na ação do transporte ${ }^{5}$.

Retornando a André Leroi-Gourhan ou mesmo pensando em outros teóricos da evolução humana como Richard Leakey (1995) e Robert Foley (2003), vemos que o próprio movimento de andar, de caminhar parte de um desequilíbrio do nosso corpo. Assim, estar apoiado somente sobre os membros inferiores e querer se deslocar, necessariamente exigirá uma mudança de ritmo ocasionada pelo desequilíbrio do corpo na posição ereta. Ao passo que para Leroi-Gourhan “os ritmos, pelo menos para o sujeito, são criadores do espaço e do tempo; espaço e tempo só existem como vividos na medida em que se tenham materializado num invólucro rítmico. Os ritmos também são criadores de formas.” (Leroi-Gourhan, 2002: 117).

Desse ponto, podemos começar a pensar no transporte público. Levando em conta o aprendizado pelo homem dos ritmos da natureza, configura-se um tempo socializado que,

\footnotetext{
${ }^{4}$ Refiro-me ao clássico estudo de Bronislaw Malinowski intitulado Argonautas do Pacífico Ocidental: um relato do empreendimento e da aventura dos nativos nos arquipélogos da Nova Guiné melanésia publicado no Brasil pela Abril Cultural em 1978.

${ }^{5}$ Para um melhor entendimento sobre o uso que Gilbert Durand faz dos gestos dominantes e sua relação com os grandes eixos do imaginário, vide o item Método de convergência e psicologismo metodológico na Introdução da obra referenciada.
} 
para Leroi-Gourhan, “implica em um espaço humanizado, integralmente simbólico, de modo que o dia e, na noite, ocorram em horas fixas nas cidades (...)” (Leroi-Gourhan, 2002: 128). Além de termos nosso tempo regulado pelo relógio, passamos a ter nosso tempo regulado pelo horário em que nosso transporte passará ou mesmo no horário em que há menor fluxo no trânsito. Nosso ritmo passa a depender do ritmo dos deslocamentos, dos fluxos, da energia que pulsa a vida na cidade e no âmbito da qual, acomodamos nossos itinerários urbanos. Mas a agitação da vida nos tempos modernos reflete a rapidez, a efemeridade, a agitação como referências culturais do ritmo de vida cotidiana, tanto quanto a compressão dos tempos e dos espaços (Giddens, 1991). Claude Lévi-Strauss (1993) já havia assinalado tal problema ao chamar a atenção para os perigos do crescimento urbano

Partindo de Lévi-Strauss e de Leroi-Gourhan podemos pensar não só uma miniaturização do ser humano em relação ao ritmo da natureza como também a gigantização do ser humano expressa nas cidades moderno-contemporâneas. Inspirados na obra sobre o imaginário de Gilbert Durand (2001) podemos conceber os meios de transportes coletivos como expressões de símbolos teriomórficos. Imaginário que se evidencia na própria escrita de Leroi-Gourhan (2002) sobre o advento do transporte mecânico “o século XIX produziu monstros que, em grande parte, ainda hoje sobrevivem, máquinas sem sistema nervoso que requerem o concurso constante de um parceiro humano...” (Leroi-Gourhan, 2002: 46).

Não é difícil se imaginar dentro de um ônibus ou automóvel a partir dessa citação. Assim como ao imaginarmos a situação descrita por Lévi-Strauss ou mesmo olharmos uma avenida movimentada do alto de um prédio, relembrarmo-nos de uma carreira de formigas transportando alimento para o formigueiro. Ambas as coisas assustadoras, o que, segundo Durand, é a agitação, o fervilhar - tanto dos veículos quanto das formigas! - que “... imediatamente, revela a animalidade à imaginação e dá uma aura pejorativa a multiplicidade que se agita” (Durand, 2001: 73-74). Quanto ao gigantismo a homologia consiste em vermos os veículos como indivíduos, em uma avenida movimentada ou numa auto-estrada não há espaço para o pedestre. O indivíduo humano só irá ter relevância amalgamado com esse ser maior, seja um carro ou um ônibus. Como aparece exemplificado na própria fantasia de alguns filmes modernos como Transformers e animações como Carros.

Podemos também nos utilizar dos símbolos catamórficos - que em Durand (2001) vão agrupar as imagens dinâmicas relativas à queda e segundo o qual representa o tempo vivido, para pensarmos a velocidade tão almejada no trânsito. Posto que ao buscar conter o tempo ou 
melhor aproveitá-lo, acelera-se em busca de economizá-lo. Podemos pensar na velocidade e na vertigem que a mesma proporciona em homologia com a sensação da queda, porém não vertical e sim horizontal, vemos que na tentativa de conter o tempo deparamo-nos com as interrupções brutais que representam os acidentes de trânsito ou mesmo outros incidentes que possam interromper o fluxo natural da rua causado pela transgressão da velocidade.

Ao aliar as teorias de André Leroi-Gourhan com Gilbert Durand - inspirado e guiado pelos ensinamentos das professoras Ana Luiza e Cornelia - acredito ser possível traçar o trajeto antropológico do transporte público. Mesmo em Porto Alegre, com nossos poucos anos de história podemos traçar tal trajeto e estudá-lo dentro de uma cultura do trânsito a partir do estudo da Companhia Carris Porto-Alegrense.

Partindo desde os transportes mais simples como as carroças e diligências, o portoalegrense vai conhecer a primeira linha de transporte coletivo em 1865 com a chamada maxambomba - espécie de bonde puxado por mulas. Serviço que opera de forma negligente e logo é extinto, até que em 1873 surge o primeiro serviço de bonde, ainda tracionados pelas mulas, com a Companhia Carris de Ferro Porto-Alegrense. E é em 1908 que começaram a trafegar os primeiros bondes elétricos em nossa pacata província. Mas, com os primeiros automóveis da cidade também surgiram serviços privados de ônibus em meados da década de 1920, serviço que ameaçou a Carris de extinção. É somente em 1966 que a Carris irá adquirir seus primeiros ônibus e assim começar a colocá-los no lugar de algumas linhas de bondes. Até que em 1970 o serviço de bonde é extinto por completo.

Nesses longos anos de história a Carris tem deixado marcas profundas no habitante da capital gaúcha. Marcas que são resgatadas a partir de crônicas e narrativas não só dos antigos funcionários da empresa como também de antigos moradores que partilham dessa memória e tiveram seu cotidiano transformado pelos itinerários urbanos tanto nos bondes quanto nas atuais linhas de ônibus. Memória que é constantemente revivida no ato de reviver a cultura do trânsito e dos deslocamentos pela cidade.

\section{A pesquisa em movimento: peripécias etnográficas no interior do ônibus}

“Imagine-se o leitor” dentro de um ônibus em movimento. O deslocamento é difícil. Pessoas carregadas de sacolas de compras, de apetrechos de trabalho, livros, crianças. Esse dia a dia do trabalhador urbano eu experimentei não mais somente como aluno carregando 
livros, mas agora como pesquisador portando uma máquina fotográfica, ou um gravador ou uma filmadora. A permissão do motorista é essencial, ele que é o guardião dessa instituição.

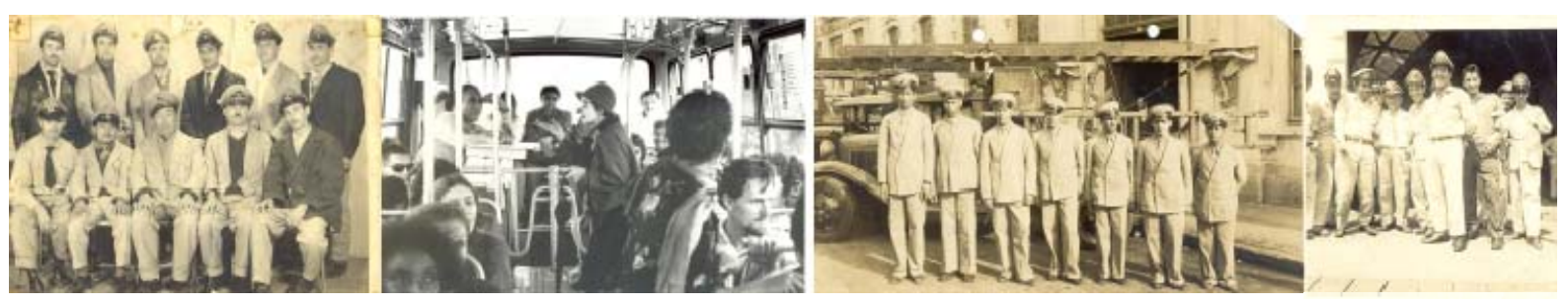

O espaço do ônibus, sobretudo pelo seu movimento, acaba se tornando um espaço de descanso, de estudo ou mesmo um espaço neutro. Onde podemos potencializar o nosso tempo em quanto nos deslocamos pelo nosso itinerário botando o sono ou conversas em dia ou mesmo estudando. Mas como se distanciar de algo mais do que familiar, algo que é quase mecânico?

O primeiro passo que segui, sob as orientações de Cornelia Eckert e Ana Luiza Carvalho da Rocha, foi embarcar ou "tomar” um ônibus no seu terminal de embarque e me deslocar pela cidade até o seu fim de linha. Realizei tais exercícios com o ônibus "linha Universitária - D43”. Observei e aprendi várias coisas que estão sendo etnografadas e descritas ao longo do trabalho. Porém, tal exercício me mostrou e ensinou coisas novas mas não gerou o famoso distanciamento ao familiar que ensinou o antropólogo Gilberto Velho (1980).

Sob os mesmos auspícios, fui realizar uma narrativa fotográfica da mesma linha de ônibus citada. O roteiro que havia preparado era fotografar desde as pessoas que aguardavam o seu transporte na parada de ônibus, as mesmas subindo no veículo, eu já dentro do ônibus fotografando as pessoas embarcando e o deslocamento do ônibus pelo seu itinerário. Acompanhando a correria e o alvoroço que ocorre quando o ônibus está chegando à parada e a interação delas com o cobrador. Como era a primeira narrativa que estava fazendo, busquei acompanhar o deslocamento dos passageiros também pelo interior do veículo e os mesmos desembarcando do ônibus no Campus do Vale, fim de linha do ônibus fotografado.

A partir das fotografias tiradas abriu-se um novo universo para mim. Não só achei muito interessante realizar tais fotografias como vi que elas estavam me mostrando um novo campo de possibilidades. Resolvi, então, sair para fotografar o D43 novamente. Não peguei o ônibus do mesmo horário e sim outro que sai uma hora mais tarde. Já era outro modelo de 
ônibus. Era o modelo de acessibilidade universal, ainda tido como os melhores modelos que circulam pela cidade de Porto Alegre. Dessa vez me propus a fotografar somente o interior do ônibus. O foco eram os passageiros e seus gestos e posturas.

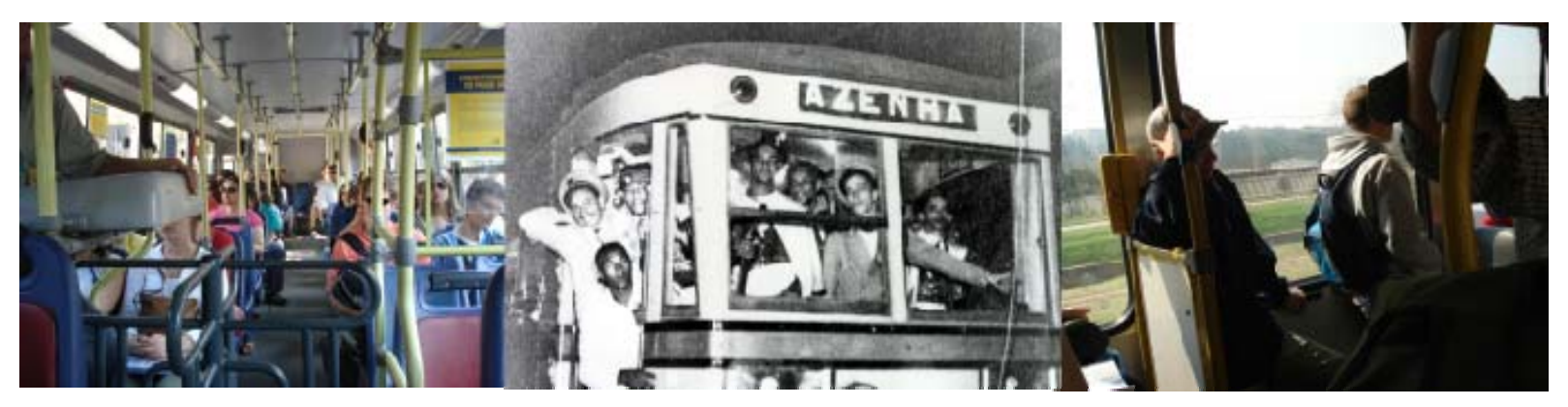

O que gostaria de salientar com essa reflexão é a fundamental importância do olhar distanciado que a fotografia me propiciou nesse hábito já banalizado no meio urbano como é o se deslocar de ônibus pela cidade. Somente com a observação etnográfica não estava conseguindo o necessário distanciamento e relativização do deslocar-se pela cidade. Foi necessária a aplicação da Antropologia Visual para me aprofundar no campo. Já analisando as fotos e tentando montar uma narrativa com as mesmas que, andando de ônibus novamente, percebi que estava olhando com o olhar do “outro” e já não mais com o olhar de nativo.

Sugiro, portanto, que a Antropologia Visual além de nos permitir mais recursos metodológicos de captação da realidade estudada, acrescenta-nos uma forma de "olhar” ou “ouvir” diferente do nativo, principalmente quando o nativo somos nós. Ela é um campo da Antropologia que nos faz enxergar o universo de pesquisa sob outro prisma, gerando uma nova forma de distanciamento do pesquisador-nativo ante sua realidade social. Sendo assim, fundamental para se pesquisar na cidade.

\section{Inserção em campo}

Minha primeira visita e inserção em campo ocorreu no dia 23 de outubro de 2006 em uma tarde tranqüila e amena, típica de Porto Alegre. Cheguei na Carris sem qualquer contato prévio e, como dizem, somente “com a cara e a coragem”. Não sabia se seria recebido, mas tampouco me importava, visto que desde o meu ingresso no BIEV já havia se passado quase seis meses e eu ainda estava sem um “campo etnográfico oficial”. Precisava exercitar tudo o que estava aprendendo e também precisava me distanciar dos antigos álbuns sobre Porto 


\author{
Alegre bem como das Revistas do Globo, dos quais tinha enorme prazer em ler, folhear, \\ selecionar fotos e inseri-las no projeto BIEV. Conforme meu diário de campo:
}

Cheguei na empresa às $15 \mathrm{~h} 30$ e apresentei-me na recepção como estudante da UFRGS, perguntando se alguém poderia me atender sem hora marcada. Falei que o assunto era uma pesquisa que estava sendo desenvolvida no PPGAS/UFRGS dentro do BIEV e gostaria de ter um contato com alguém, mesmo que breve e sem querer atrapalhar. A recepcionista que me atendeu chama-se Maiara e ela me pôs em contato com a Roberta, estagiária da Assessoria de Imprensa. Ainda na recepção, expliquei para a Roberta sobre nosso interesse em estudar a memória coletiva de Porto Alegre e a vantagem de termos a Carris como uma empresa diferenciada das outras, não só por ter muitos anos de história e tradição, mas também por demonstrar uma forma de trabalho e atendimento ao público especial.

Vencida esta etapa, Roberta me levou à sala da Assessoria de Imprensa e me apresentou à sua chefa, Luzia Marques Lindenbaum. Luzia estava ocupada com questões burocráticas e pediu para Roberta me apresentar alguns de seus trabalhos e o museu itinerante da Carris. Roberta me apresentou o museu e falou brevemente sobre um projeto de reforma do mesmo. Voltamos para a sala da Assessoria de Imprensa e vimos muitas fotos sobre os veículos da Carris e sobre uma Porto Alegre de outra hora. Conversando com Roberta, descobri que ela cursa História na UFRGS e analisamos várias imagens, momento no qual pude colaborar com a descoberta de detalhes que haviam passado em branco. Após meia-hora fui recebido por Luzia que, além de demonstrar interesse, já me apresentou alguns funcionários em outro breve passeio pelas dependências da empresa. Mostrou-me o lugar preferido dos funcionários, um galpão com umas três mesas de bilhar, lugar que, segundo ela, escutam-se as melhores histórias dos motoristas e cobradores (e que está ameaçado de extinção), informação que Luzia me passou com ar grave e preocupado. Expliquei para Luzia sobre o trabalho e minhas intenções como pesquisador, respondeu-me que por ela não haveria problema, mas teríamos que falar com o diretor para eu conseguir o aval final. Continuamos caminhando e foi no corredor que conheci o Sr. João Jesus - funcionário há 15 anos e mais conhecido como Peludo. Não entendi direito seu papel na Carris, mas Luzia falou que ele já havia sido, e era, algo como funcionáriomodelo e/ou algo como presidente da Associação dos Funcionários. Peludo se pôs ao meu dispor para ajudar na pesquisa com entrevistas e o que mais fosse necessário. Falou-me também em que local o encontraria facilmente na empresa que, infelizmente, não consegui memorizar devido ao excesso de informações. Seguimos nosso caminho para a sala do diretor e, após a Luzia falar com a secretária e pedir que a mesma nos avisasse quando ele estaria disponível, tomamos um café e voltamos para a sala da imprensa. Pouco tempo depois, fomos contatados e seguimos rumo à sala do diretor. Passando a recepção com a sala da secretária, seguimos por um corredor no qual havia a sala dos três diretores da empresa. Chegamos à última, sala do diretor administrativo. Seu nome é Régis e ele impressiona pelo seu tamanho, quase não cabe atrás de sua mesa, e isso que é uma mesa enorme. Por um breve instante fiquei nervoso, mas comecei a falar e sua reação era a de um olhar de quem estava mais sondando as minhas intenções do que me escutando. Percebendo isso, parei de tentar explicar a pesquisa de forma acadêmica e falei sobre nossos princípios éticos de pesquisa. Até então ele só havia me escutado, depois disso ele perguntou o que eu precisaria da empresa. Falei que precisaria de acesso às dependências da Companhia e de autorização para entrevistar, fotografar e filmar a firma e os funcionários. Sua resposta foi lacônica: “Tá! Tudo bem! Era só isso?” Sentindo que era hora de sair, pedi licença, agradecendo mais uma vez e retornei para a sala da assessoria de imprensa. Poucos minutos depois, Luzia retornou e disse-me que tinha que fazer uma autorização formal e por escrito com o intuito de eu poder circular e me identificar perante os funcionários. A autorização não demorou a ficar pronta e foi nesse intervalo que chegaram à sala o Chefia e o Mestre de Cerimônias. 
O Chefia é o segundo funcionário mais antigo da Carris e é o motorista oficial do museu itinerante da empresa. É um senhor grande, corpulento, de cabelos grisalhos e muito, muito simpático. Observei-o enquanto conversava com a Roberta e outro rapaz. Pouco depois, entra no recinto outro senhor, que denominei Mestre de Cerimônias. É um senhor alto, esguio, de cabelos grisalhos e muito eloqüente. Entrou no ambiente falando sobre alguma conquista para os funcionários, mudando de assunto, pouco depois, para falar do drama de algum funcionário acidentado que teria de amputar a perna. Escutei-o falando (tudo isso da salinha da Luzia, ambiente com uma separação quase simbólica) que este senhor ainda estava inconsciente e que não saberia se ele iria querer a prótese que ele e os outros funcionários estavam querendo conseguir. $\mathrm{O}$ Mestre de Cerimônias se lamentava pelo colega que além brincalhão, se esforçava para fazer os outros rirem.

Após esses breves episódios, a minha autorização ficou pronta e após agradecer novamente a recepção, despedi-me. Neste momento o Chefia levantou-se para abrir a porta para mim e aí pude ter meu primeiro contato com ele. Ele disse que abria a porta para eu voltar e eu lhe disse que era isso que mandava a tradição. Ele riu e me despedi de vez. Já havia se passado uma hora e meia e já estava cansado. Retornei ao BIEV e iniciei a redação desse diário de campo. Muito feliz pela boa vontade e receptividade dos meus futuros informantes em me atender.

Desse dia em diante passei a acompanhar o Memória Carris, museu itinerante criado na década de 1980 pelo então prefeito Alceu Collares sob decreto municipal e hoje conduzido pelo senhor Eloy Barcelos, um dos funcionários mais antigos da Carris.

\section{Personagens da etnografia}

Meus entrevistados são habitantes que tiveram ou uma estreita aproximação com a história da Cia. Carris Porto-Alegrense, como o caso da Dona Narion - ou que contam com muito tempo de serviço na empresa como Antônio Souza Costa e Eloy Barcelos, atualmente os dois funcionários mais antigos da Carris. Personagens que falam de outra Porto Alegre, uma Porto Alegre de poucos carros e ônibus, carroças e bondes. Bondes que duram na memória não só deles, mas também dos habitantes que nasceram até a década de 1960 e nos falam de outro ritmo urbano.

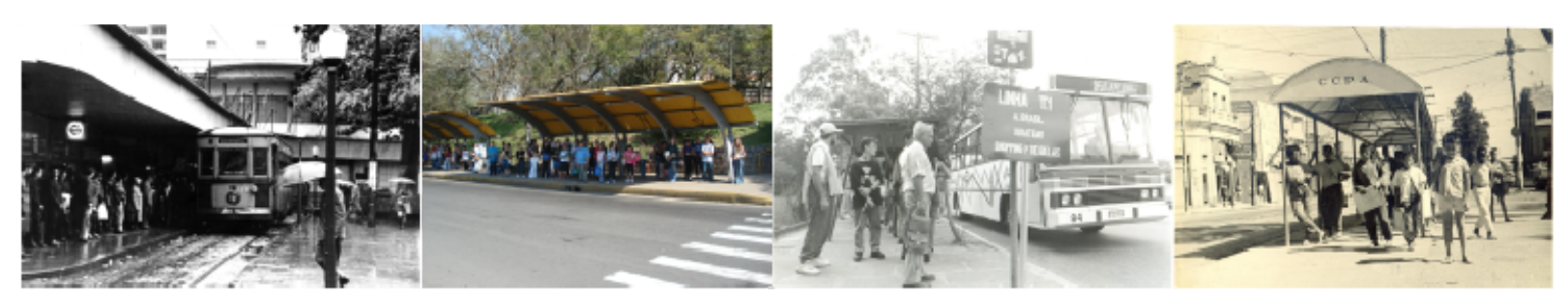

Antônio Souza Costa, o Seu Antônio, entrou na empresa há “um bocado de tempo" como ele me relata em uma entrevista realizada em 07 de outubro de 2008. Seu Antônio é o funcionário mais antigo em serviço da Carris e da história da Carris, ingressou na empresa em 
16 de dezembro de 1947 um ano após ter vindo de Cruz Alta/RS, onde nasceu em 1923. Conheci o Seu Antônio no final de 2006 conforme relato no meu diário de campo

Seu Antônio é o responsável pela sala de leitura e passa seus dias ali. Cheguei no recinto e logo me apresentei para ele, ao ser indagado se era um novo funcionário da empresa, aproveitei a oportunidade e falei de nossa pesquisa. Perguntei-lhe se ele se importava de conversar comigo, me dar entrevistas, etc. e ele disse que não havia problemas, que estava ali sempre das $8 \mathrm{~h}$ às $12 \mathrm{~h}$ e das $13 \mathrm{~h} 30$ às $18 \mathrm{~h}$. Porém, hoje ele não poderia me atender, pois estava ocupado. Seu Antônio é um senhor muito simpático, disse que me mostraria seu livro sobre um método para medir QI's e outras coisas através das impressões digitais. Contou-me que era coordenador pedagógico de profissão, dizendo isso com muita pompa. (30 de novembro de 2006).

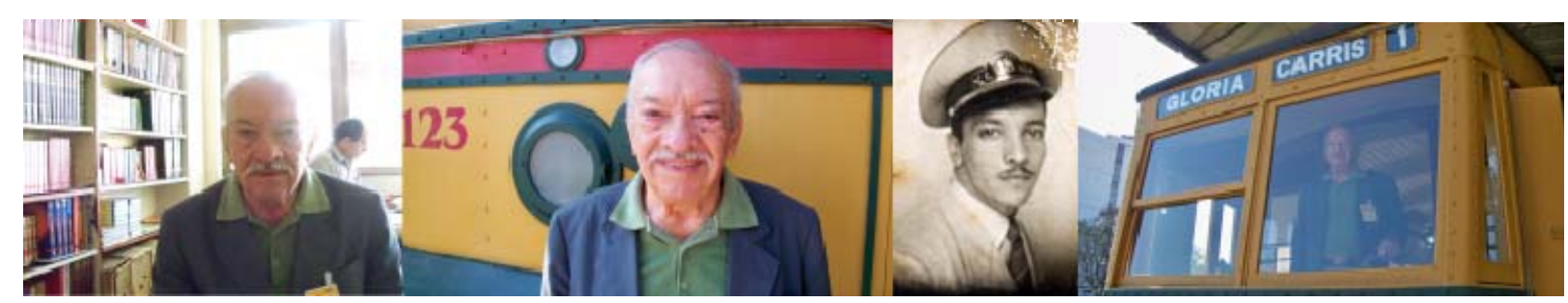

Na entrevista supracitada Seu Antônio narra

Fui um ano condutor de bonde, depois dirigi bonde durante mais um ano... Aí precisaram de datilógrafo e eu era datilógrafo então fui pro escritório... Departamento de Pessoal... e então lá eu fazia a admissão de novos funcionários, tudo, tinha de botar a impressão digital lá na ficha do funcionário... Eu não entendia nada de Datiloscopia, mas eu notei que um determinado desenho aquele candidato tinha mais facilidade de compreender o que ele lia sobre o contrato de trabalho, o regulamento da empresa assim, né... Aquilo me chamou a atenção, então comecei assim a ver as impressões digitais de cada um e terminei publicando um livro que eu dei o nome de Datilopsicologia...

Seu Antônio - em uma de minhas visitas a Carris, contou-me que havia participado de um Congresso de Egiptologia em Londres, na Inglaterra. Onde fora chamado para analisar as impressões digitais de algumas múmias egípcias. Convite fruto da publicação de seu estudo em Datiloscopia. Certa vez perguntei ao Seu Antônio

Henrique: E como é que era Porto Alegre naquela época? Quando o senhor começou a trabalhar na Carris...

Seu Antônio: É, Porto Alegre era bem menor, mas... foi crescendo tão lentamente que a gente não... quase não nota, né?!

Henrique: E o trânsito na época...

Seu Antônio: O trânsito na época era muito mais livre, tinha menos movimento, né... $E$ as linhas de bonde, tinha os trilhos de bonde pela cidade toda e agora já não tem mais...

No mesmo diálogo, que contava com a presença da Débora (monitora do Museu Memória Carris entre os anos de 2007 e 2008), ela pergunta 
Débora: E o senhor lembra de algum acidente que tenha ocorrido na época dos bondes?

Seu Antônio: Bom, comigo não, graças a Deus nunca tive nenhum acidente!

Débora: Nenhum acidente?

Seu Antônio: Nenhum!

Henrique: Mas era normal ou era raro assim?

Seu Antônio: Era menos movimento conseqüentemente tinha menos acidente que hoje em dia, né... Mas eu graças a Deus nunca me vi envolvido em nenhum!

Neste ponto cabe nos familiarizarmos com a Dona Narion, como é carinhosamente chamada pelos amigos, a senhora Narion de Porto Ávila, que tem sua história de infância estreitamente ligada a Cia. Carris. Dona Narion é uma senhora muito alegre, faceira e elegante como ela não só transparece, mas como se orgulha de ser. O pai da Dona Narion trabalhou na Carris a vida inteira, como ela narra em uma entrevista que conta com a participação de sua filha Maria Tamara Porto de Ávila

Dona Narion: Era a Carris... e meu pai trabalhava ali. Ele era... primeiro ele foi cobrador, depois ele foi motorneiro - que era o que dirigia, né [risadas]... depois disto ele foi fiscal, de dentro da Carris e depois fora, nos bondes, né... [Henrique: sim...]. Tinha aqueles bondes gaiola que quase jogava a gente... a gente entrava numa porta e quase jogava a gente na outra, né... porque ele gingava muito, né... e fazia esse... era uma cobrinha! o bonde gaiola era uma cobrinha! Fazia esse... [ruído de telefone...] Mas era muito conhecido e todo mundo gostava... [Tamara: a gente fervia muito nesse bonde gaiola, era uma brincadeira!]... é... é, era sim...
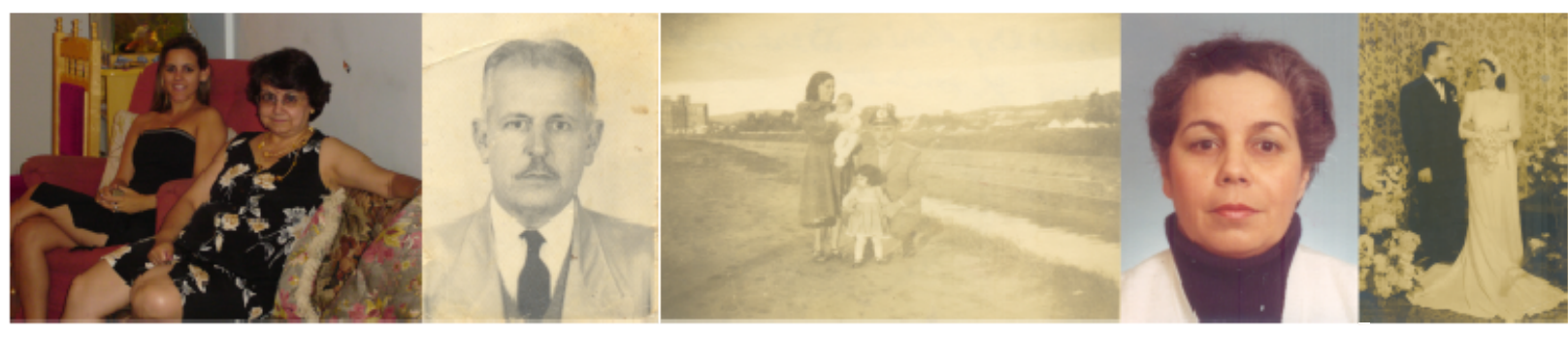

Pergunto a Dona Narion se ela chegara a conhecer a sede da Carris em que seu pai trabalhou e, para minha surpresa, não só conheceu como

Dona Narion: Sim! Eu vivia ali dentro [Henrique: Aé!?] Eu vivia ali dentro, porque eu perdi minha mãe com 4 anos, era bem pequenininha e o meu pai morava logo depois da Carris, né, nós crianças, não tinha ninguém que nos cuidasse, nós botava o pé pra rua e pimba! Lá pra Carris! que era na mesma calçada, né... Então o pai vivia dentro da Carris e lá na Carris tinha aqueles buracos grandes assim - que eu não sei te dizer o nome - Tamara: pra consertar o bonde por baixo. Dona Narion: É, nós adorava descer aquilo ali... Então nós vivia dentro da Carris. E o meu pai trabalhava ali o dia todo e de noite ficava em casa porque tinha medo de nos deixar sozinha, éramos quatro filhos, quatro filhos. Eu tinha 4, a minha irmã tinha dois aninhos, dae tinha o rapaz, que era o filho, tinha 6 aninhos e a mais velha era a menina que tinha 8 
aninhos que era a mais velha de todas. Então vivia lá dentro da Carris com meu pai, pulava... era uma moleca! Pulava dum lado pro outro, entrava numa porta, saia na outra. Ajudava os homens a tirar o bonde dali de dentro! Hehe! Era muito divertido, era bom! Então nunca sai dali, fui criada ali dentro... [Henrique: mas vocês moraram ali sempre?] Sempre... Depois é que meu pai saiu dali e mudou-se para a 17 de Junho que antigamente era a Rua dos Coqueiros. Agora que é... a famosa Rua dos Coqueiros. Agora é a 17 de Junho. Aí sim, aí nós já távamos maiorzinha e o pai já não deixava a gente sair porque ali já era mais longe...

Dona Narion e Tamara relembram como era bom e divertido andar de bonde em suas respectivas épocas, lembranças que se amalgamam e se distendem através da história dos transportes coletivos, chegando não só a descrever o antigo processo de cobrança dos trocadores (ou condutores como também eram conhecidos os cobradores dos bondes) como a problematizar atual sistema de cobrança de tarifas (o cartão TRI) nas narrativas a seguir

Dona Narion: ...tinha aqueles bondes gaiola que quase jogava a gente... a gente entrava numa porta e quase jogava a gente na outra, né... porque ele gingava muito, né... e fazia esse... era uma cobrinha! o bonde gaiola era uma cobrinha! Fazia esse... [ruído de telefone que interrompe sua fala...] Mas era muito conhecido e todo mundo gostava... [Tamara: a gente fervia muito nesse bonde gaiola, era uma brincadeira!]... é... é, era sim...

Risadas... Tamara: Tu está falando dos bondes gaiola? ... Dona Narion: Ah!!! é... dos bondes gaiola... do bonde gaiola, tinha... tinha diversos dos bondes gaiolas, tinha o bonde gaiola. Mas era um bonde muito gostoso, muito divertido. [Tamara: quem fazia a farra eram as crianças!] é... e os bancos eram tudo de madeira, né... era tudo de madeira, não tinha posto não tinha nada. E aqueles banco tu virava para lá e ele dava a volta... tu virava para cá e ele ia para lá... Então, porque... os trilhos, nos fim de linha e lá, aonde o bonde entrava - para a Carris - eles torciam o trilho... Eles metiam uma alavanca, eles tinham uma alavanca. [Tamara: é que nem trilho de trem...] Isso mesmo! É o mesmo, né! Aí eles viram o trilho para o outro lado e o bonde da a volta normal, né... [Tamara: era um vagão só!] ...é, é... [Tamara: porque chegava no fim da linha, giravam aqueles negócios ali, aquelas alavancas... passavam por dentro do bonde, iam lá do outro lado, colocavam as alavancas de novo. Aí vinha outro atrás - o cobrador - puxando os bancos, virando os bancos...] é, é... não tinha nada dessas coisas, desses que tem agora os ônibus... esse ônibus, né... que tu fica trancada numa roleta ali, um bocado de tempo e ainda leva um... ouvindo um mundo de desaforo porque... cartãozinho não passa ali e tu tem que esperar, e a filinha atrás... os bondes não tinha nada disso, entrava numa porta e saía lá na outra. Oh, beleza! [Henrique: Como é que funcionava, assim, o cobrador, ou trocador , ele...] ele cobrava, ele... [Henrique: ...pagava ou ele ia indo...] Não!!! Ele ia cobrando um por um, ele ia cobrando um por um. Aí fazia a volta por fora do bonde e vinha para a frente de novo [Tamara: e tinha a passagem escolar] é... [tá! A gente comprava, tinha uma carteirinha , aí ganhava umas tripas assim, que a gente cortava. Então eram umas passagenzinhas como isso aqui ó... era um pouquinho mais estreita e mais cumpridinha. E aí... \{Henrique: tipo uma passagem de metro hoje?\} [Não, eram de papel e aí eu me lembro que tinha a foto de um bonde assim. E aí vinha Companhia Carris e a data e o ano, que cada ano era diferente, era uma cor diferente.]

Dona Narion: E bem baratinho que era também, né! \{Henrique: Mas mais ou menos quanto assim?\} Um centavo, é... um centavo! Depois foi para 1 e 50 depois foi para 20 centavos. Era coisa pequena assim, né... não era caro! Então todo mundo só queria andar de bonde, né!

\{Henrique: Já tinha ônibus na época também ou...\} Tinha ônibus , não da Carris, né... Era o ônibus que apareceu depois que terminaram com os bondes. Aí ficou só com os ônibus, né. Aí desapareceram os bondes, não tem mais bondes por causa dos ônibus... 
[Tamara: Tinha! Tinha umas...] Tinha um ônibus, não... era... [Tamara: tinha no Menino Deus, no Maracanã...uma espécie de ônibus...] não, era... não era ônibus, aquilo era... como é que chamavam... o troleybus que tinha uma... [Tamara: não! Aquele veio depois...] É, depois dos bondes! Depois que terminaram... [Tamara: Era um ônibus elétrico, não tinha trilho, mas ele tinha um cabo, que nem o bonde...] É... esse já foi o segundo... o bonde, bonde mesmo... [Tamara: Era um bonde melhorado! Risadas].
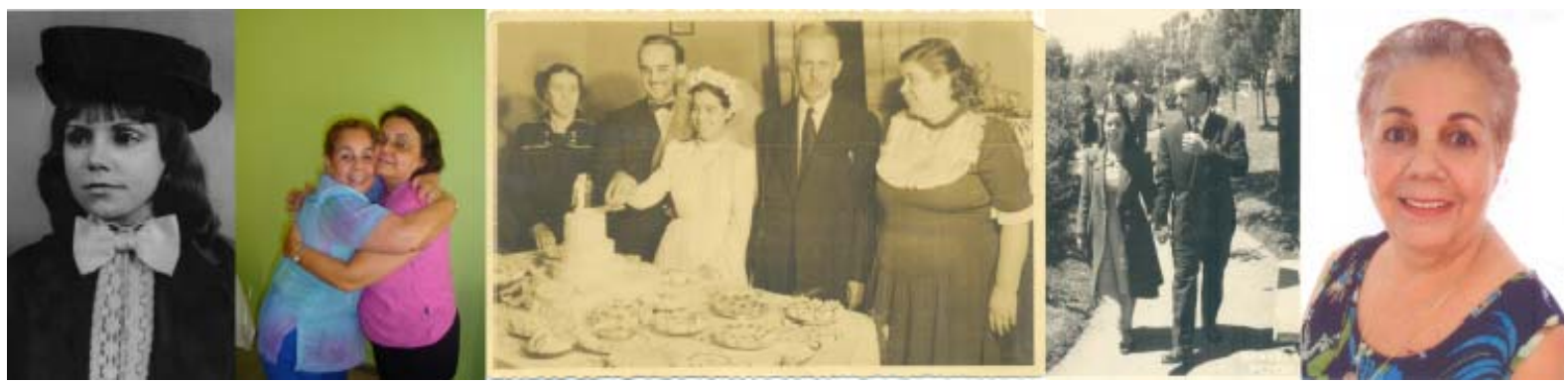

Pergunto a Dona Narion como ela aprendeu a andar de bondes, se havia recebido instruções de seu pai (já que fora um especialista no assunto), na tentativa de resgatar parte de um saber hoje já modificado através do tempo.

Dona Narion: Não... isso a gente aprendeu por conta porque tava sempre junto, então... aprendia, né... não tinha... só tinha que se segurar beeem! Esses gaiolas principalmente se tu facilitava tu entrava numa porta e saia na outra! Porque eles jogavam muito, como eu já te disse né... mas eu me lembro que o teste dos guri, dos gurizão assim como tu! [Tamara: O teste era viajar nas portas do bonde!] É!!! [Tamara: Os guris não entrava e sentava nos bancos, ficavam nas portas...] Se agarravam... [Tamara: Se agarravam com os pés assim né...] Não... tinham uns cumpridos... [Tamara: Tinha uns cumpridos acima e abaixo para se agarrar e se agarravam ali... de madeira... eu me lembro era uns... sabe a porta da clínica? Tinha aquele negócio mas grande e o agarrador era de metal, douradinho assim... e o coiso era de madeira, o miolo ali onde agarravam mesmo era de madeira. E o teste dos guris era ficar na porta dos bondes. Quando era gaiola então! Ahahahaha!!!]

Dona Narion: Porque o gaiola é o mais, mais sacudido, né! [Tamara: E descer com o bonde andando!!!]

Henrique: Descer com o bonde andando era..

Tamara: E descer com o bonde andando... quando ele ia parando o bonde e fazia aqueles barulhos de metal, do cara travar e o metal da roda no trilho, os guris desciam com o bonde andando! Ahh, não podia... com o bonde parado era só para mulher! Ahahaha!!!

Dona Narion: É... o bonde andando era, olha era chic, era lindo! É...

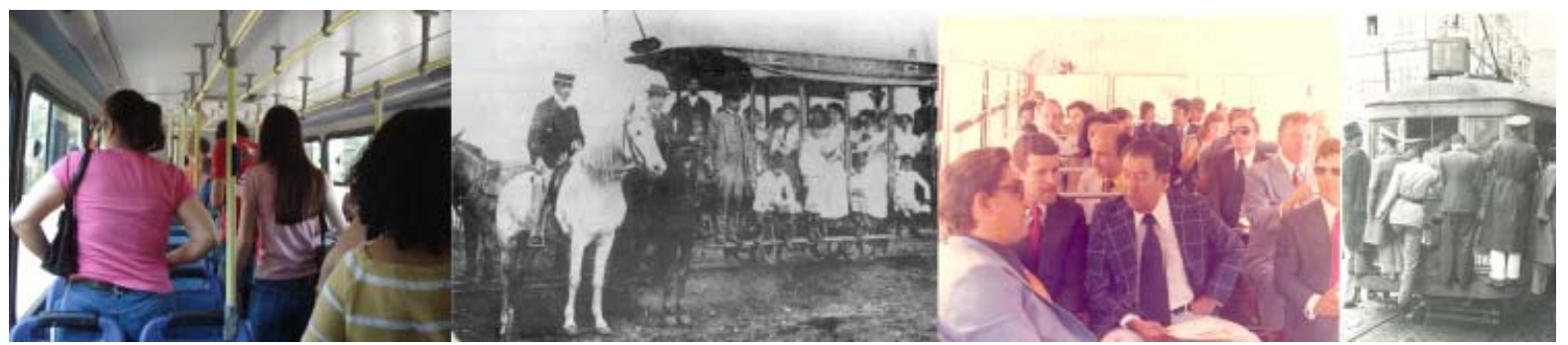


No meio da narrativa, ao descreverem essa espécie de "rito de passagem” e fator de virilidade que se caracterizava pelos homens "andarem dependurados” nos bondes é que aparece o assunto dos acidentes que ocorriam com esse meio de transporte e dos quais o próprio Sr. Porto, pai de Narion, foi vítima.

\footnotetext{
Dona Narion: Desses bondes, desses bondes gaiolas eu até me lembro de um acidente com meu pai... É... Ele vinha todo exibidão, né... meu pai era muito faceiro, era outra Narion! Bem faceiro, bem bonitão, bem garmado. E ele vinha nesses bondes gaiola, mas vinha agarrado mas só com uma mão assim, né... E o motorneiro lá invés de fazer a curva pra entrar na Carris, fazer a curva com calma! Tinha um monte de areia que eles tavam arrumando e ele fez a curva rápido e escapou a mão do meu pai... e meu pai assim ficou enterrado naquela areia! Ahahahaha! [Tamara: Ainda bem, hein!!!] É... eu e meu irmão tava lá e a gente viu e começou a gritar "olha o pai, olha o pai!" Tava lá enterrado! Ahaha! Mas é nesses bonde gaiola, ele jogava! Era muito bom esses bonde! Hehehe! Mas é só... os outros não, os outros andavam direitinho, andavam na linha!

Henrique: Andavam na linha que nem se diz...

Dona Narion: É! Andavam na linha. Os bondes gaiola tu vai encontrar muita história, dos bondes gaiola...

Henrique: Eu ia perguntar... hoje se vê bastante acidente, né... isso aí como é que funcionava? Tinha? Mais o pessoal caindo do bonde...

Dona Narion: É... sim, por causa disso...

Tamara: Era mais exibicionismo! Hahaha!

Dona Narion: É!!! Porque eles ficavam dipindurados...

Henrique: "Eu sou homem logo tenho que ficar dependurado..."

Dona Narion: É... os bonde não tinham porta... eles ficavam dependurados e aonde escapava uma mão... as vezes o bonde tava andando e eles vinham e batiam com o pé assim! Então dá aquele coisa na pessoa, né... E eles adoravam fazer isso! Então de vez em quando um, além do pé escapava uma mão lá. Aí dava um acidente, né! Tamara: Ehehehe!

Dona Narion: Que nem meu pai! Deixou escapar a mão, ele vinha com a outra mão se exibindo todo, né... quando escapou a mão lá em cima... o bonde, bem na hora que o bonde fez a guinada pra entrar ele entrou no monte de areia! Aterrissou no monte de areia!
}

A narrativa de Dona Narion e da Tamara sobre a prática de "ficar dependurado" nos bondes me lembra experiências de adolescente em que era prática comum entre os garotos que andavam de bicicleta “pegar carona nos ônibus” que circulavam pela periferia da cidade. A prática, de alto risco por sinal, consistia em o ciclista ou se agarrar nas barras de apoio que ficavam no lado externo das portas dos ônibus ou fixaram seus pés no pára-choques traseiro do veículo com a finalidade de percorrem qualquer distância em grande velocidade. Entre os adolescentes do sexo masculino funcionava como uma "prova” para ver se o sujeito era realmente homem.

Com esses dois exemplos podemos retomar Simmel com o já citado "sentimento de depreciação" que acomete alguns sujeitos, mas que também podemos associar a uma busca de 
diversão e aventuras como demonstra o diálogo entre dois senhores - funcionários do Colégio Americano - que visitaram o Museu Memória Carris quando o mesmo foi convidado a ir ao colégio em 17 de outubro de 2007. Eis um trecho do diário de campo:

Não foi uma simples visita daqueles senhores pelo museu improvisado no interior do velho ônibus e sim uma viagem pela memória deles! Eles olhavam as réplicas dos antigos bondes e relatavam histórias como bah!!! Que loucura meu! Que saudade daquele tempo! Esses bancos aqui... eles viram, né?! Olha ali um gaiola! A gente andava dependurado neles! Cada foto que eles viam, remetia a uma lembrança ou pequena narrativa. Ao olharem uma foto com vários homens dependurados em um bonde um prontamente disse Bah! Muito que eu andei assim! Pegávamos os bondes sempre lotados! Geralmente a gente andava até sem pagar passagem! Quando o trocador vinha nos cobrar, a gente descia do bonde e subia no outro lado. Ele ia atrás da gente de novo e a gente fazia a mesma coisa! Bons tempos aqueles... hehehe! $\mathrm{E}$ assim ficaram, vagando por suas nostálgicas lembranças até que um deles os traz à realidade Dae! Tá bom, mas temos que voltar ao trabalho!!! E assim partiram os três senhores para sua lida diária. (17 de outubro de 2007).

Por fim, cabe apresentar o principal informante dessa pesquisa etnográfica, o senhor Eloy Barcelos, mais conhecido dentro da Carris por Chefia, já é história dentro da empresa. Dono de um carisma incrível e muito sociável, nosso amigo e narrador Chefia é um dos funcionários mais antigos da Carris.

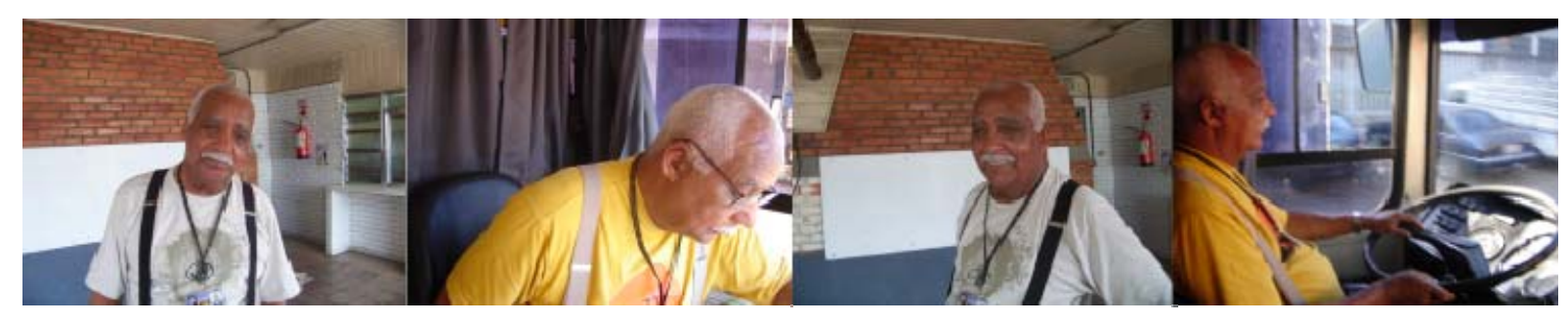

Entrou “na época dos bondes” mas não chegou a conduzir um. Chefia atualmente trabalha dirigindo o ônibus Memória Carris. Ônibus monobloco Mercedes-Benz de 1984 que, segundo Chefia, as pessoas chamavam tal modelo de "bolinha" na época em que ainda transportava passageiros pelas ruas da cidade. É um museu paradigmático, visto que é um museu itinerante e que leva em seu interior parte da história de Porto Alegre associada a história da Companhia Carris e da evolução do transporte público na urbe.

Porém, nem sempre “o Memória” teve essa configuração. Em 18 de março de 1988 é criada pelo decreto municipal 9.125 a "Memória Carris", pelo prefeito municipal de Porto Alegre Alceu Collares. Inicialmente esteve localizado em uma sala anexa ao antigo Centro de Treinamento da empresa, contando também com uma versão itinerante na época, porém sabese muito pouco de sua rotina e funcionamento. Entre outras coisas, o Decreto prevê como 
objetivos da Memória Carris "preservar a memória da antiga Carris, empresa que através de seus bondes fez parte da vida quotidiana do porto-alegrense” (1988).

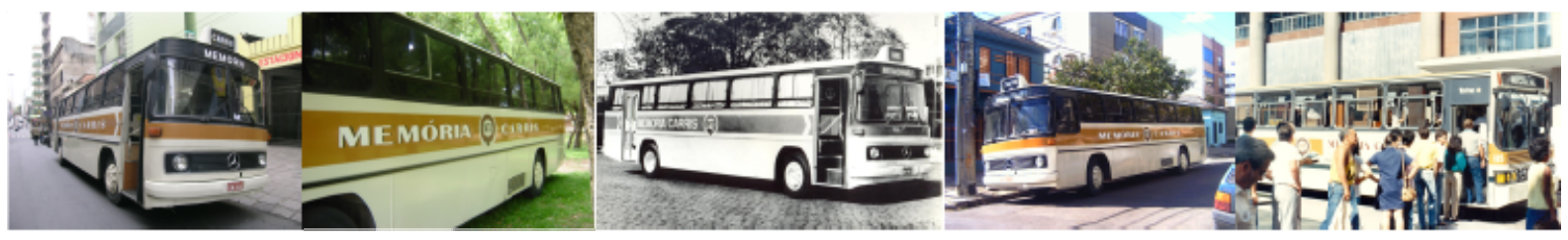

É somente em 1995 que o museu itinerante será instalado dentro do ônibus monobloco Mercedes-Benz de 1984 e quando deixará de existir o museu fixo na empresa. De lá para cá, sofreu modificações em sua forma de expor a memória da Carris. Segundo o PréPlanejamento do Projeto Memória (2001) de reestruturação do museu itinerante objetiva-se

transmitir ao visitante um pouco da história do transporte público e também a história da empresa Companhia Carris Porto-Alegrense (Projeto Memória, 2001).

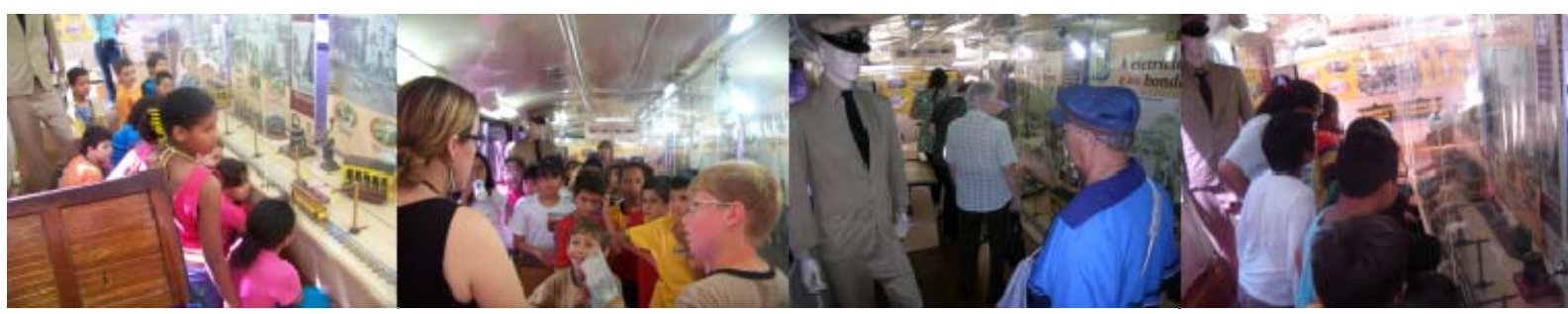

Hoje, após 21 anos de sua fundação, pude acompanhar “o Memória Carris” em sua função social de fazer durar a memória dos bondes e do transporte coletivo em Porto Alegre. “O Memória Carris” resgata a lembrança dos bondes e a nostalgia dos antigos meios de transporte público da capital gaúcha (que chegou a ter o maior acervo de bondes em operação do mundo nas décadas de 1950 e 1960). “O Memória” exotiza a antiga cidade permitindo a continuidade da memória coletiva que passa a ganhar novos adeptos - na maioria das vezes as crianças - para fazer a memória durar e transpassar o seu antigo quadro social (Halbwachs, 2006).

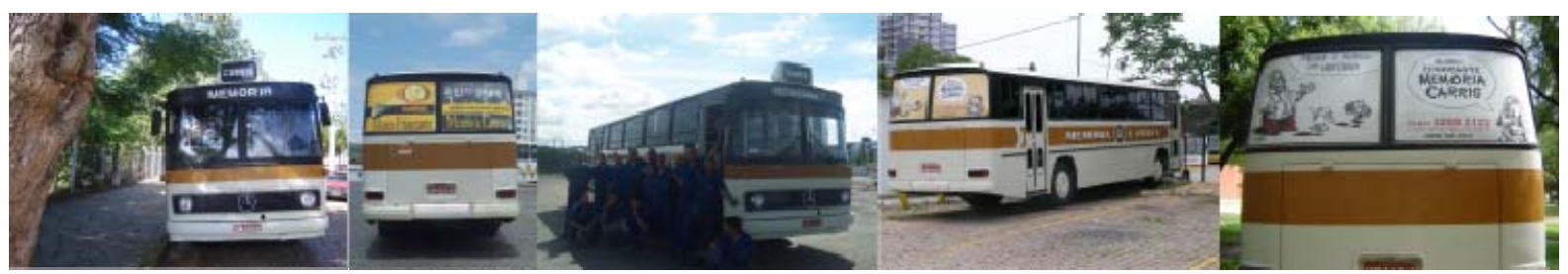


Chefia entrou na Carris como mecânico, pois já havia trabalhado anteriormente como mecânico aeronáutico na Real Aerolíneas. Disse-me que, mesmo não sendo sua função original, dirigiu ônibus por alguns anos. Chefia também passou por diversos lugares do Brasil antes de se estabelecer em Porto Alegre e começar a trabalhar na Carris. Trabalhou com turismo e, por conta disso, viajou muito. Morou até mesmo por um período na capital argentina de Buenos Aires. Após conduzir diversas linhas de ônibus e de ter retornado a sua função original, Chefia foi instrutor da Escola de Motoristas da empresa por alguns anos. A Débora me conta que esse é um dos motivos da grande popularidade do nosso ídolo, do nosso favorito amigo Eloy Barcelos, o Chefia. Chefia costuma brincar com seus amigos dessa forma “Oh meu ídolo! Tu é o meu favorito!!! Eu sou teu fã, Chefia!” Eis o motivo dele ter a alcunha de Chefia, chamar afetuosamente todos de Chefia.

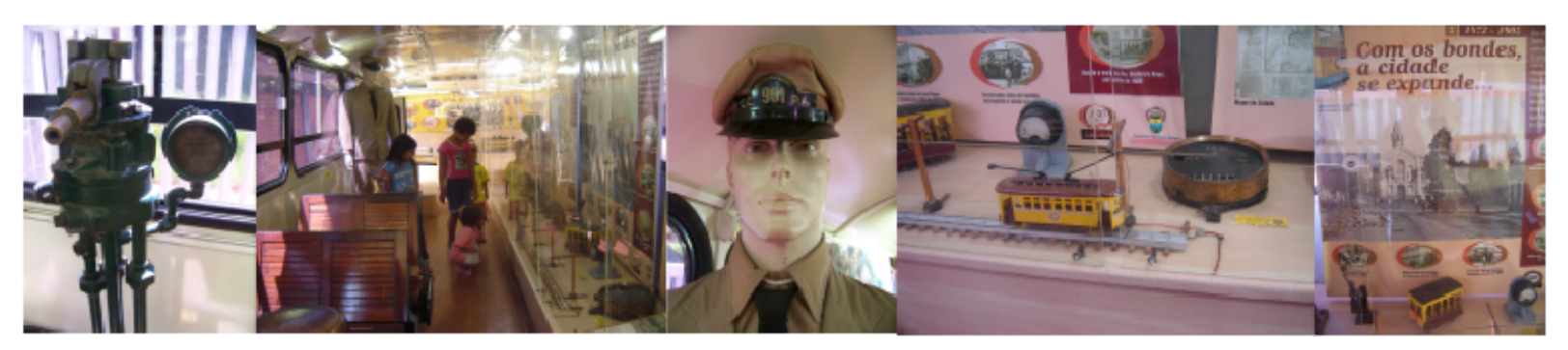

Chefia não só conduz “o Memória” como é também o responsável pela manutenção do mesmo. Zela também pelo ônibus-museu onde quer que ele esteja aberto a visitação. Chamando a atenção das crianças travessas, com muita seriedade e eficácia, porém cai na risada após elas se alinharem. Comenta sempre que “se deixar, elas tomam conta!”. Com sua boa conversa, Chefia está sempre pronto a receber os antigos moradores e ajudar a resgatar memórias comuns sobre o cotidiano da antiga cidade. Chefia, de seu banco de condutor, sempre convida as pessoas que olham com ar desconfiado da porta dianteira do veículo para ingressarem no museu “Pode entrar, Chefia! Tá aberto ao público!”.

Tal museu conta com peças de bondes como acelerador, relógios de marcação de passageiros, bancos reversíveis e réplicas de bondes, uma coleção de antigas passagens de bondes e ônibus e um manequim vestido com o elegante traje dos motorneiros e condutores (denominação dos antigos cobradores) dos bondes. Os tripulantes fixos desse ônibus são o Chefia e um estagiário do curso de História. Desde que iniciei a pesquisa passaram duas 
estagiárias, Roberta Durán (estagiária nos anos de 2005 e 2006) e Débora Vogt que trabalhou nos anos de 2007 e 2008 junto ao Museu Memória Carris.

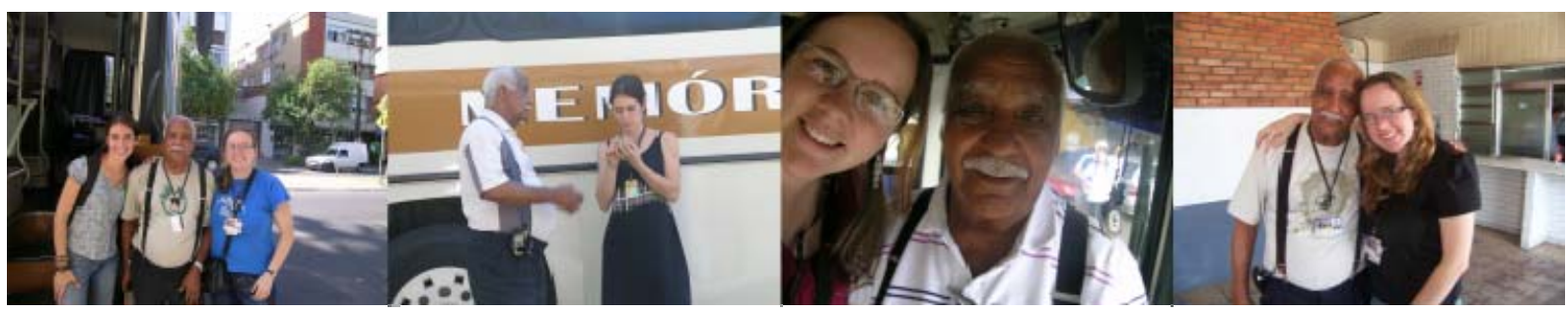

Geralmente o Chefia fica em seu assento enquanto a Débora (estagiária do museu no período em que eu mais o acompanhei) recebe incontáveis turmas de crianças, contando sempre dos inícios do transporte público em Porto Alegre e do advento dos primeiros bondes puxados por burros. Narra aos pequenos a instalação dos bondes elétricos em 1908, a última viagem de bonde em 1970, as transformações urbanas ocorridas na cidade (como a mudança da sede da Carris da Avenida João Pessoa para a Rua Albion), explicando também como funcionava os bondes. As narrativas frequentemente são acompanhadas pelos suspiros nostálgicos dos professores e funcionários que acompanham a garotada nos colégios visitados. Fato que também ocorre quando o museu itinerante se encontra em praças e parques da cidade e recebe a visita de diferentes gerações, como idosos acompanhados de seus filhos e/ou netos.

Mais recentemente, Chefia foi transformado em personagem de história de quadrinhos, como narrador principal da história da empresa:

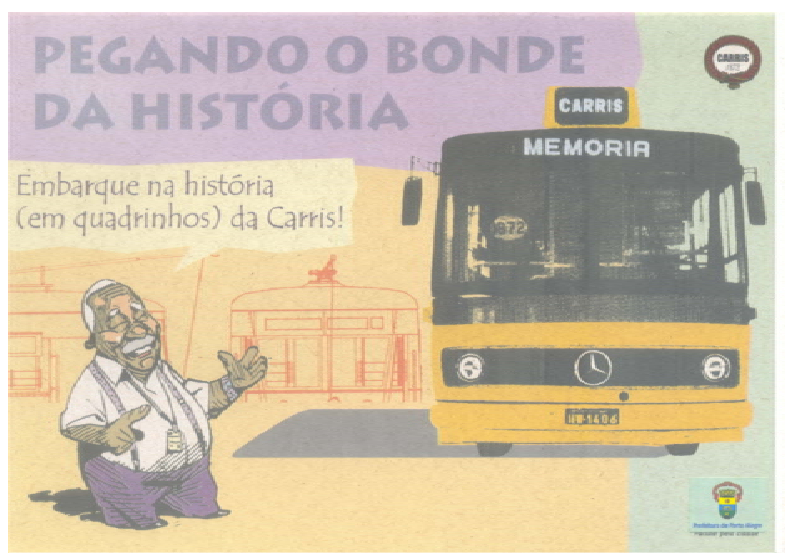

Esta é, de forma bem divertida, a história da Companhia Carris Porto-Alegrense, a empresa de ônibus mais antiga do Brasil, em funcionamento, e uma das mais antigas do mundo.

O Museu Itinerante Memória Carris, é literalmente um "museu sobre rodas", isto mesmo, um museu montado dentro de um antigo

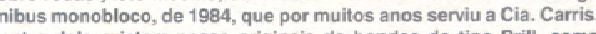
Dentro dele existem peças originais de bondes do tipo Brill, como der, bancos, passagens e "bonds". Um monitor de história

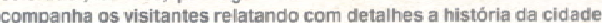
eda evoluçāo do transporte coletivo.

Embarque em nosso "ônibus-museu" e conheça os diversos momentos que marcaram a cidade de Porto Alegre e a vida de sua população. Apresentamos a voces o motorista desta viagem: o Sr. Eloy, conhecido como "Chefia', trabalhador antigo da empresa, que

-Memória", como é conhecido, está sempre presente nos principais eventos culturais de Porto Alegre.

Será um prazer levar a história até vocế! 

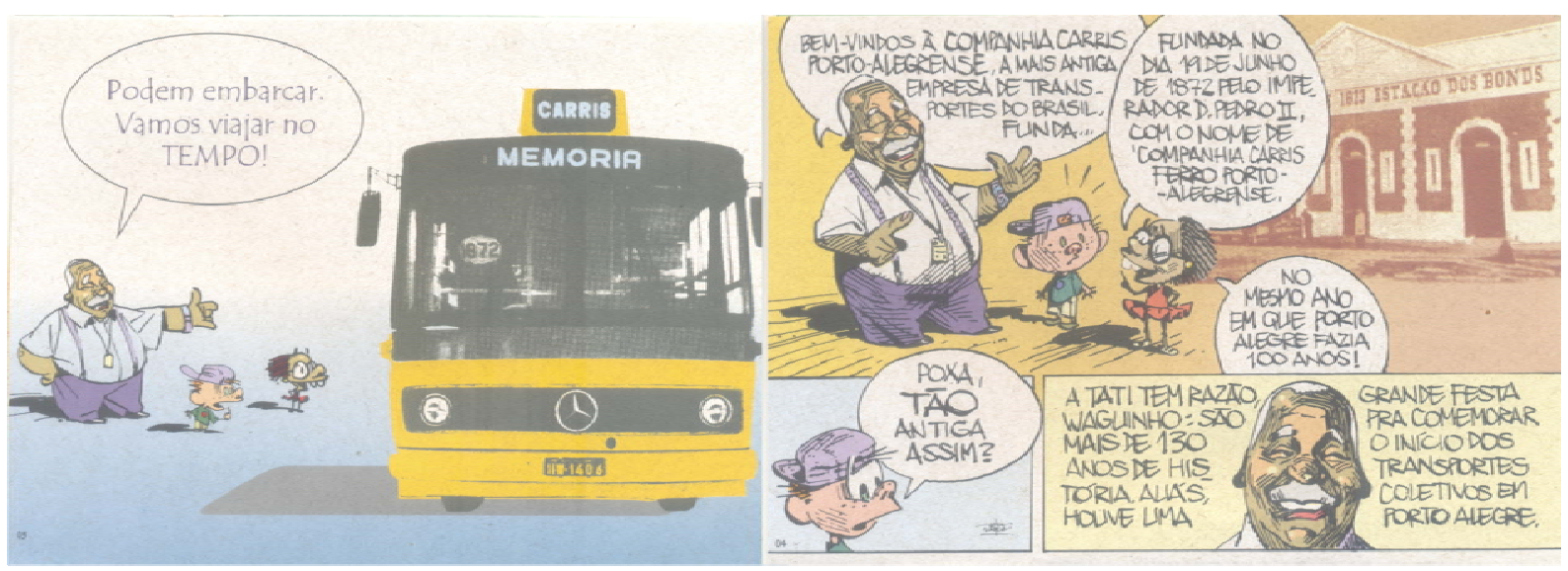
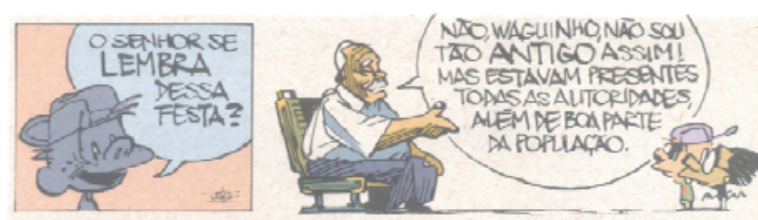

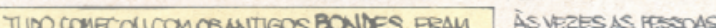
COMPEA MOSBCHHHO,

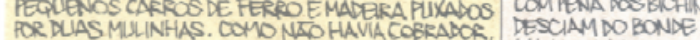
AS PESTMS COMPRAVAMTRMETES: OS'BONDS', NA HORA DE

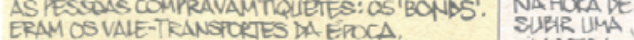

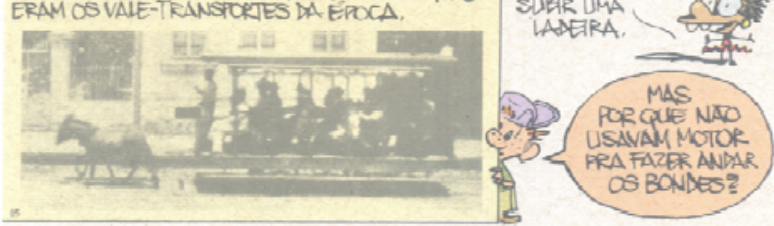

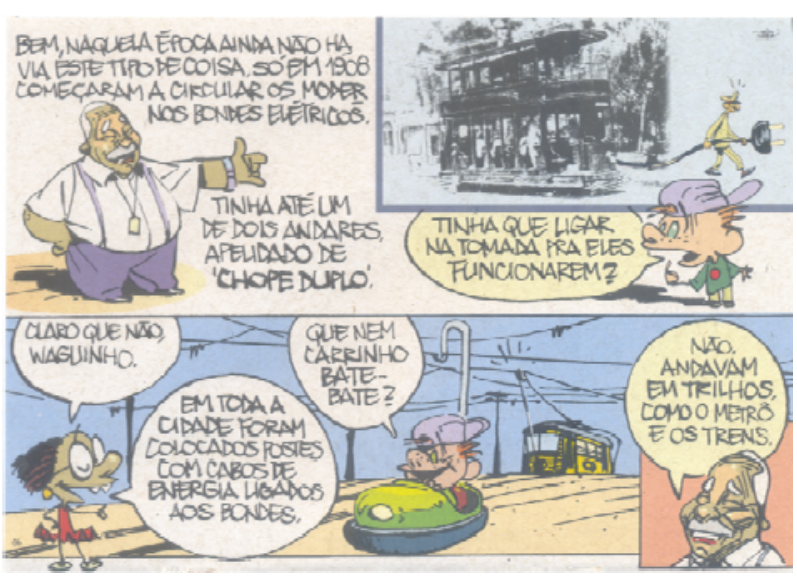

MAS NAO DAVAM CHOQUE? NAD, OS BONDES ERAM SEGU. TANTO QUE FORAM

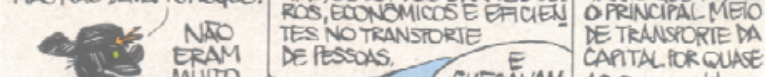
EMESUO!ES LANTDS? NEM ERANASCIDO, MAS SEI QUE FOOM EM 1929 que ACAKEIS COMECOUA ULAR

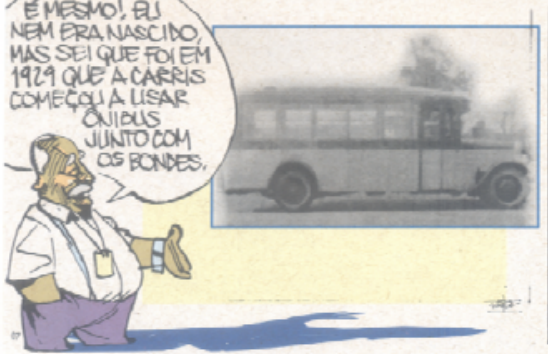
100 $\mathrm{km} / \mathrm{h}$.

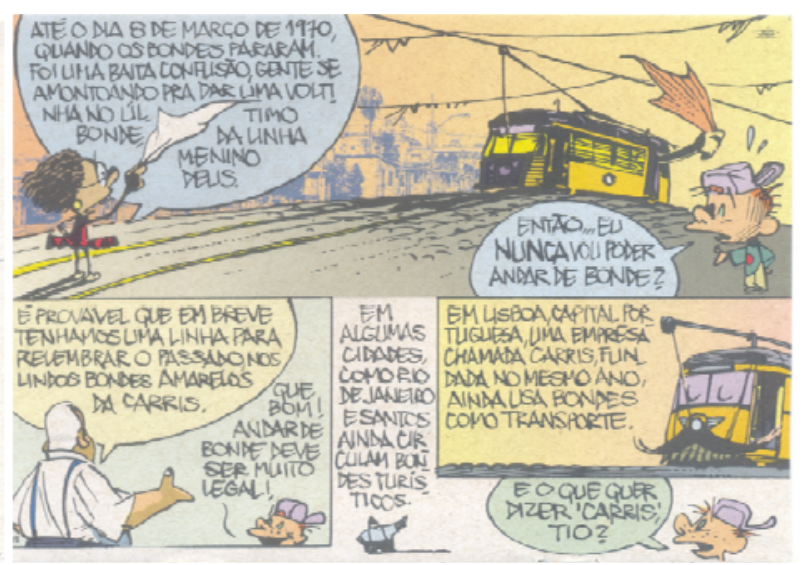




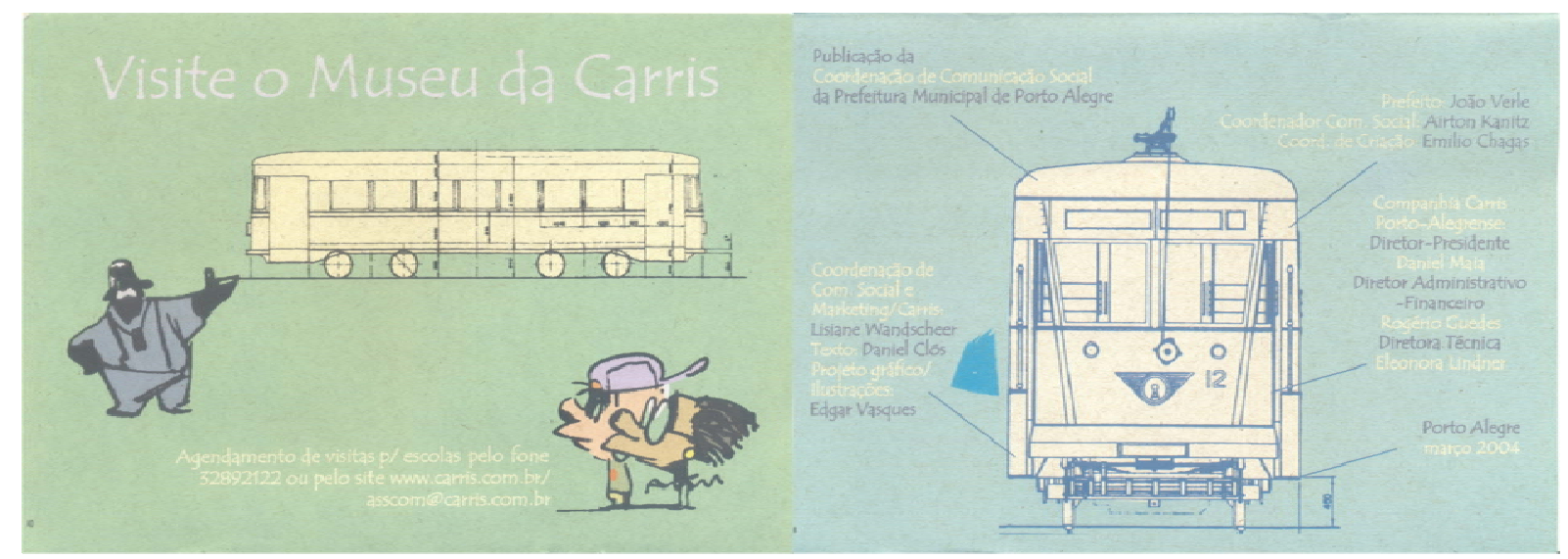

\section{Aspectos conclusivos}

“O Memória Carris” é um lugar privilegiado para observarmos “o jogo de memórias” que o visitante é “convidado” a jogar, evocar imagens lembradas de tempos vividos e lembrados em Porto Alegre ou qualquer outro lugar de deslocamento de sua experiência e a do trajeto humano que ritma as memórias em uma dialética da duração, para novamente recorrer a obra de Gastón Bachelard e o projeto do BIEV.

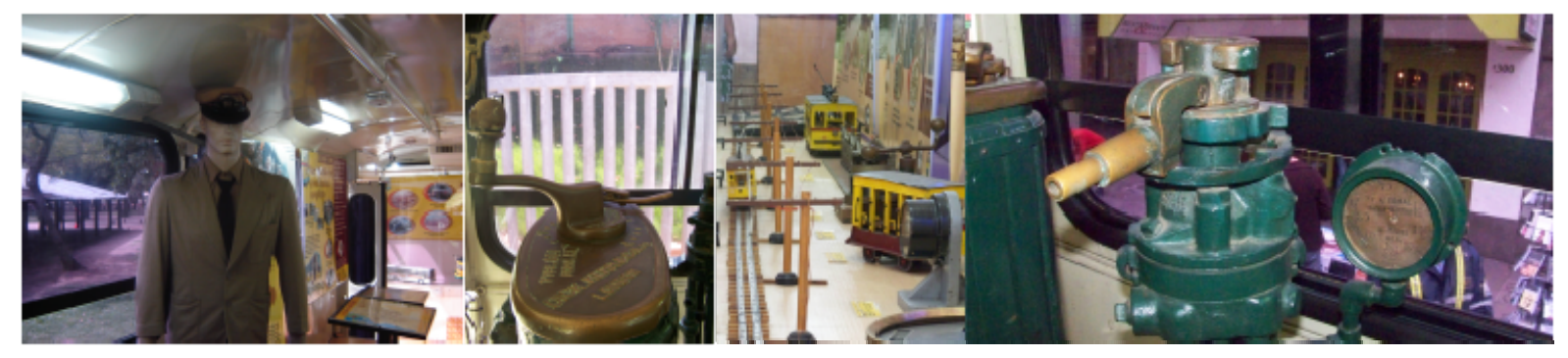

As imagens que trago evocam e fazem ressoar outras imagens, como sugere o artigo de Eckert e Rocha (2009). Fiz várias “viagens” com o ônibus Memória Carris. Minha intenção era conhecer, nessas "saídas etnográficas” a forma como a Carris divulga sua “memória oficial”, mas, sobretudo, para conhecer Chefia em sua vocação de guardião da memória, fato comprovado com Chefia sendo imortalizado ao ser transformado em personagem e narrar a história em quadrinhos da Carris, fato que corrobora o seu papel de guardião da memória para recorrer a um tema caro ao antropólogo francês autor do livro $A$ Memória Coletiva (2006), Maurice Halbwachs. Nessas incursões vi os meios de transporte e o 
trânsito serem privilegiados "na narração do sujeito e em suas reminiscências no jogo de sua vida cotidiana evocando locais, passagens e itinerários significativos da vida urbana local gravados na sua memória”.

Quanto a cultura do trânsito em Porto Alegre, em um futuro próximo acena-se para mudanças urbanísticas em decorrência de ser uma das cidades escolhidas para sediar jogos na Copa do Mundo de Futebol de 2014.

Perante esse cenário que se anuncia, o próprio Museu Memória está em vias de modificação. Recentemente abriu um concurso pela Carris para a mudança do layout do ônibus-museu que, em breve, deixará de apresentar a pintura clássica dos ônibus da Carris da década de 1980. E assim, vemos mais um ruído temporal sumir nas contingências do tempo. Memórias continuarão a se deslocar, imagens continuarão a se movimentar.

\section{Referências}

BACHELARD, Gaston. A Dialética da Duração. São Paulo: Editora Ática S.A., 1994. CARDOSO DE OLIVEIRA, Roberto. O trabalho do antropólogo. São Paulo: Unesp, 2000.

CARRIS 130 anos: relatos da história e outras memórias. Organizado pela Companhia Carris Porto-Alegrense. Porto Alegre: Secretaria Municipal da Cultura, 2002.

DE CERTEAU, Michel. A invenção do cotidiano: artes de fazer. Petrópolis: Editora Vozes, 1994.

DECRETO Municipal da Prefeitura de Porto Alegre n 9.125. Cria a “Memória Carris" e dá outras providências. Porto Alegre, 18 de março de 1988.

DIÁRIO Gaúcho de 16 de novembro de 2006. Matéria, Na mira dos ladrões

DURAND, Gilbert. As Estruturas Antropológicas do Imaginário: introdução à arquetipologia geral. São Paulo: Martins Fontes, 2001.

ECKERT, Cornelia. A cidade “com qualidade” Estudo de memória e esquecimento sobre medo e crise na cidade de Porto Alegre In: Revista Sociedade e Cultura. Revista de Pesquisas e Debates em Ciências Sociais. Universidade Federal de Goiás. Volume 10, numero 1, jan/jun 2007. p. 61 a 80.

ECKERT, Cornelia e ROCHA, Ana Luiza C. Etnografia na rua e câmera na mão. Revista Studium, Instituto de Artes Campinas SP, v. 8, p. 1-10, 2002 http://www.studium.iar.unicamp.br/oito/2.htm

ECKERT, Cornelia e ROCHA, Ana Luiza C. O tempo e a cidade. Porto Alegre: Editora da UFRGS, 2005.

ECKERT, Cornelia e ROCHA, Ana Luiza C. Etnografia da duração: estudos de memória coletiva. In: BERND, Zilá et alli (Org). Memória e cultura: perspectivas transdisciplinares. Canoas, Unilasalle, Mestrado Memória Social e Bens Culturais, 2009.

FOLEY, Robert. Os humanos antes da Humanidade: uma perspectiva evolucionista. São Paulo: Editora UNESP, 2003.

GEERTZ, Clifford. A Interpretação das Culturas. Rio de Janeiro: LTC Editora, 1989. GIDDENS, Anthony. As conseqüências da modernidade. São Paulo: Unesp, 1991. HALBWACHS, Maurice. A Memória Coletiva. São Paulo: Centauro Editora. 2006. http://coisasurbanas.blogspot.com/2007/12/tri.html . Acesso em 05 dez. 2007. 
http://www.intelog.net/site/default.asp?TroncoID=907492\&SecaoID=508074\&SubsecaoID=9 48063\&Template=../artigosnoticias/user_exibir.asp\&ID=290916\&Titulo=Mudan\%E7a\%20n os\%20\%F4nibus\%20divide\%20idosos . Acesso em 28 nov. 2007.

http://memoriacarris.blogspot.com/

http://picasaweb.google.com/museuvirtualcarris

http://www.cidades.gov.br/noticias/mcidades-confirma-400-milhoes-para-copa-em-porto-

alegre?searchterm=Porto+alegre+e+copa . Acesso em 17 nov. 2009.

http://www.mp.rs.gov.br/memorial/clips/id13651.htm . Acesso em 18 mar. 2008.

http://www.ppp.portoalegre.rs.gov.br/

http://www.tripoa.com.br/

http://www2.portoalegre.rs.gov.br/

http://zerohora.clicrbs.com.br/

LEAKEY, Richard. A Origem da Espécie Humana. Rio de Janeiro: Rocco, 1997.

LEROI-GOURHAN, André. Evolução e Técnicas. I - O Homem e a Matéria. Lisboa:

Edições 70, 1984.

LEROI-GOURHAN, André. O Gesto e a Palavra. 2 - Memória e Ritmos. Lisboa: Edições 70, 2002.

LÉVI-STRAUSS, Claude. A civilização urbana e a saúde mental. In: Antropologia Estrutural dois. Rio de Janeiro: Edições Tempo Brasileiro Ltda. pp. 290-293.

MALINOWSKI, Bronislaw. Argonautas do Pacífico Ocidental: um relato do empreendimento e da aventura dos nativos nos arquipélogos da Nova Guiné melanésia. São Paulo: Abril Cultural, 1978.

Manual de Procedimentos: Fotografia e Internet. Banco de Imagens e Efeitos Visuais.

MAUSS, Marcel. Sociologia e Antropologia. São Paulo: Cosac Naify. 2003.

NUNES, Marion Kruse; VILARINO, Maria da Graça de Andrade. (organização e elaboração do Centro de Pesquisa Histórica da Coordenação da Memória Cultural da Secretaria Municipal da Cultura; coordenação de Marion Kruse Nunes); texto de Marion Kruse Nunes e Maria da Graça Vilarino. Carris 120 anos. Porto Alegre, 1992.

OLIVEN, Ruben George. A Antropologia de grupos urbanos. Petrópolis: Editora Vozes, 1987.

PEGANDO o bonde da história. Texto de Daniel Clós e projeto gráfico/ilustrações de Edgar Vasques. Publicação da Coordenação de Comunicação Social da Prefeitura Municipal de Porto Alegre. Porto Alegre, 2004.

PROJETO MEMÓRIA 2001 - Pré-planejamento.

ROCHA, Ana Luiza Carvalho da. Coleções etnográficas, método de convergência e etnografia da duração, um espaço de problemas. Banco de Imagens e Efeitos Visuais/UFRGS. 2007.

SILVA, Cinara Santos da. MACHADO, João Timotheo Esmerio. Memória Carris: Crônica de uma história partilhada com Porto Alegre. Prefeitura Municipal, Porto Alegre, 1999.

SIMMEL, Georg. As grandes cidades e a vida do espírito (1903). Mana, Rio de Janeiro, v.11, n.2, out.2005. Disponível

$<$ http://www.scielo.br/scielo.php?script=sci_arttext\&pid=S0104-

93132005000200010\&lng=pt\&nrm=iso>. Acessos em 05 dez. 2009. doi: 10.1590/S010493132005000200010.

TURNER, Victor W. O processo ritual: estrutura e antiestrutura. Petrópolis: Editora Vozes, 1974. 
VELHO, Gilberto. "O antropólogo pesquisando em sua cidade: sobre conhecimento e heresia”. In: VELHO, Gilberto (org). O desafio da cidade: novas perspectivas da Antropologia brasileira. Rio de Janeiro: Campus, 1980. 